\title{
Seawater intrusion characterization based on electrical resistivity and hydrogeochemical methods; surrounding Rosetta branch area, Egypt
}

\author{
Osman Badran ${ }^{1}$, Rasha Mansi ${ }^{1}$, Elhamy Tarabees ${ }^{1}$, Maged El Osta ${ }^{2,1}$, Hend Hussein ${ }^{1}$ \\ ${ }_{1}^{1}$ Geology Department, Faculty of Science, Damanhour University, Damanhour, Egypt \\ ${ }^{2}$ Water Research Center, King Abdulaziz University, P.O. Box 80208, Jeddah 21589, Saudi Arabia
}

\section{ARTICLE INFO}

Received 30 May 2021

Available online 3 July 2021

\section{Keywords}

Seawater intrusion,

Schlumberger array,

Geoelectric,

Hydrochemical characteristics,

Vertical electrical sounding
Article history:

Received in revised form 3 July 2021

Accepted 3 July 2021

\begin{abstract}
Seawater intrusion (SWI) is one of the most common environmental issues in recent years, posing a threat to groundwater quality and sustainability, especially in coastal aquifers. The current climate changes linked to rising sea levels as well as the excessive pumping of groundwater, linked to the lack of natural recharge, have exacerbated this environmental problem. As a result, to characterize and detect seawater intrusion in this region. Because this area has a high salinity, and there is no abundance of good-distributed wells due to high salinity and lack of reliance on water wells for different purposes, it was necessary to combine these two methods to confirm the results. This paper presents a comprehensive combination of geoelectric methods represented by artificial vertical electrical soundings (VES) and hydrogeochemistry of groundwater. Vertical electrical resistivity values are obtained by Schlumberger's array of twenty-six VESes distributed all over the area using the Eleric-T device. However, the electrical resistivity sounding method succeeded to outline the aquifer depth, extension and thickness. The hydrogeochemical techniques outline the ions, cations, water types and water quality based on the chemical analysis of 26 groundwater samples. Both two types are contributed to emphasis the results. The VES results succeeded to describe the Pleistocene aquifer lithology and subdivides it into fresh, brackish and salt zones (freshwater - saltwater interface). The hydrochemical characteristics of groundwater samples through the physiochemical parameters, Chadha diagram, ionic relations and DWQI confirm the influence of SWI on the chemistry of groundwater in the concerned area. Consequently, these results confirm that the integration between the electrical resistivity and hydrochemical methods are effective tools for the characterization of seawater intrusion in this important region in terms of agricultural activity in Egypt.
\end{abstract}

\section{Introduction}

Egypt is an arid-region, and water supplies are the country's primary source of development. Egypt's primary basis for water is the River Nile, while groundwater is the second category. (Ali Hamadan, 2005). The Nile intersects the study area from the southeast to the northwest direction. It is important to note that the Nile is the main source of fresh water recharge for the aquifer; on other hand, the Mediterranean Sea is a strong water recharge for the aquifer. Naturally, there is a greater demand for fresh water than salt water. Therefore, the intrusion of seawater is increased with the over pumping of groundwater. Therefore, it was necessary to use electrical resistivity to demonstrate the aquifer affect by the Nile, and the seawater effect on the other side.

\footnotetext{
* Corresponding authors at: Damanhour University E-mail addresses: osman.badran@sci.dmu.edu.eg (Osman Badran)
}

It is necessary to combine the two methods to confirm the results at different depths in the region.

Therefore, the groundwater must be preserved, particularly following the completion of the Grand Ethiopian Renaissance Dam, and possible impacts on the quantities of the Nile River water in future. Various global climate models constructed by the Intergovernmental Panel on Climate Change (Ipcc, 2008) predict that among all the current worldwide, environmental and social changes, climate change will have severe future impacts in the Nile Delta regions. There will be a wide range of these impacts on sea level rise and on water resources, both groundwater and surface water. The IPCC expects that by the year 2100, global warming will cause sea level rise between 110 and $880 \mathrm{~mm}$, and this is predicted to lead to internal migration of the mixing area of fresh and salt water (FAO 1997). Therefore, SWI is one of the most challenging and prevalent environmental concerns that threaten the future of sustainable development in Egypt, which mainly 
depends on fresh groundwater in coastal aquifers for development, principally in the Nile-Delta of Egypt. As a result, the groundwater quality in this area could be actually affected by the interaction of seawater with changes in Nile flows, resulting in a rise in groundwater salinity and presenting a significant threat to food security. Consequently, groundwater research in this area is critical for detecting the flow path and salt-water intrusion interface, as well as determining its performance for different uses.

Many published works have investigated the hydrogeological, hydrogeochemical and geophysical settings of the area of Nile Delta. The main aquifers in the western Nile Delta, according to Abdel Baki (1983), Ismail (1994), Gomaa (1995), and Ali Hamadan (2005), are the Recent, Pleistocene, Pliocene, Miocene, and Oligocene. Structurally and based on the studies carried out by Harms and Wary, (1990), Sarhan and Hemdan, (1994) and Abdel Aal et al., (1994), The East-West, north-south, northwest (Temsahtrend), and northeast (Rosetta trend) striking faults threaten the Plio-Pleistocene sediments of the Nile Delta. Alternatively, multiple East-West trending faults sever the delta region's into land portion, which extend into other parts of Northeast Egypt (Abd-Allah, 2001and 2008). Due to the direct interaction between surface water hydraulic bodies and the aquifer of Nile-Delta.

Alewa, 2008 stated that, Groundwater present in shallow Quaternary aquifers of some stations was poor in quality and beyond potable limit, according to the standards set by WHO. The groundwater quality is satisfactory (geochemically) requires attention, with a thrust on proper salinity hazard control in the northern coastal regions. Land degradation hazard mitigation measures were also proposed. According to Fouad and Zhi (2010), any change in the water flow schedule affects groundwater levels and water balance in the region due to the groundwater/surface water relationship and complex flow system. They reached the conclusion that the region's highest groundwater levels are due to the thin aquifer thickness in this direction. Furthermore, the total amount of groundwater withdrawal for agricultural activities exceeds groundwater recharge, presenting a long-term challenge to the aquifer's capacity and sustainability, as well as the threat of saltwater invasion in the region. More recently, Al-Arabi and Morsi (2013) reported that the regional flow direction in the Nile Delta region is from south to north. Groundwater mounds are found in areas with high recharge through the downward penetration of extra irrigation water from old reclaimed projects that use the surface water system for irrigation.

The negative effects of uncontrolled groundwater extraction can arise rapidly. Potential negative impacts, which could be a depletion in the level more than $10 \mathrm{~m}$, increasing salinity levels and the costs of abstraction, associated with lower groundwater levels (Sallam, 2018). According to Parker (2001), the ability to conduct electricity is one of the most variable physical properties of minerals and rocks. Electro prospecting is a method of determining basic characteristics of electric fields or forces and then using that information to define sediments or subsurface structures in a given region (Burger, 1992). Usually, electrical methods rely on the effects of an electric flow current through underground structures on the earth's surface, then measuring the resulting comparable potential difference, from which the calculation of apparent resistance of each formation can be determined. The wide variations in electrical resistance found in various rocks and minerals, on the other hand, make applying these techniques to groundwater exploration feasible and fruitful (Telford et al., 1990). As seen, the presence of groundwater, which acts as an electrolyte, has a major effect on rock resistance, and the conductivity of the sediments increases with the amount of groundwater present. Groundwater conductivity varies greatly depending on the concentrations and forms of minerals and dissolved salts present (Burger, 1992). This is mainly true in porous sediments and sedimentary rocks, where porosity is the primary determinant of resistance, which increases as porosity decreases. Crystalline rocks with low granular porosity, on the other hand, are conductive through a fracture system filled with fresh water or salt water (Kearey and Brooks, 1998).

\section{The objectives:}

This study aimed to document the influence of seawater intrusion on groundwater aquifer and to detect the saline-freshwater interface in Northwestern Nile Delta, Egypt using vertical electric soundings and groundwater quality index, according to their plan, as follows:

1. To subdivide layers of varying resistances, rocks, waters, depths, and thicknesses in the thin sedimentary section, which are entered by electric current up to 150 meters. Vertical electrical sounding (VES) technology is used to separate these layers into areas saturated with groundwater and those empty of water (salt or fresh). The current geophysical research, on the other hand, was carried out in accordance with the Topographical, geological and hydrogeological conditions that existed in the study region.

2. To differentiate between areas of fresh water withdrawn from the aquifer in the Nile Delta and salt water entering from the Mediterranean Sea into the sedimentary portion, based on salinity, using of one-dimensional electrical resistance probing.

3. To discuss groundwater quality and confirm seawater infiltration in this region using hydrogeochemical methods.

\section{Study Area}

\section{1 location and description}

The research area lies around the River Nile in the northern Rosetta branch (Kafr El Sheikh Governorate to the east while, El Behira Governorate to the west direction). It is bounded geographically by latitudes $31^{\circ} \mathrm{N}$ to $31.5^{\circ} \mathrm{N}$ and longitudes $30.3^{\circ} \mathrm{E}$ to $30.8 \mathrm{E}$. The study area is of strategic site with determined development policies due to its historical, locational and agricultural importance. 


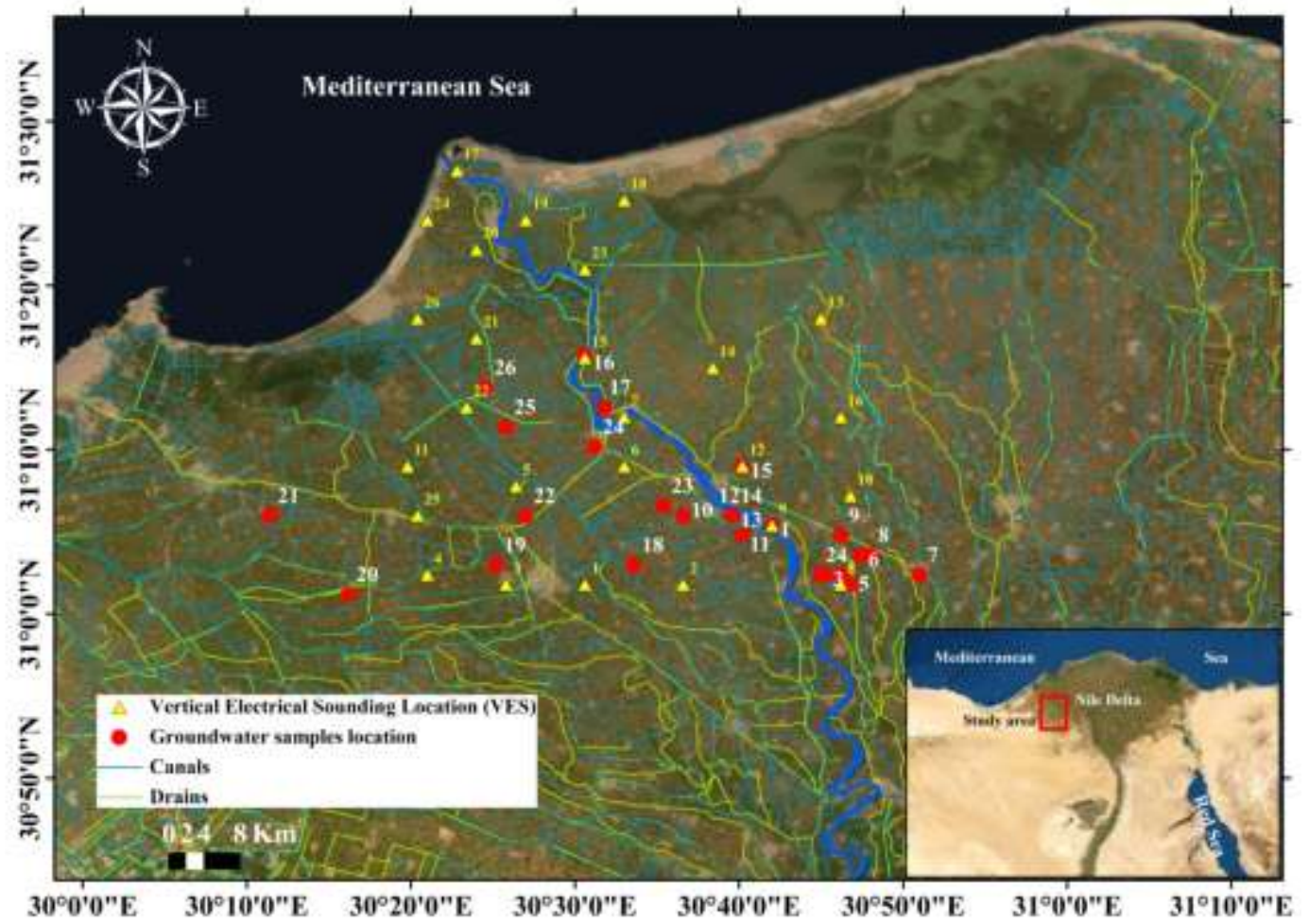

Fig. 1. The Vertical Electrical Soundings (VES) and groundwater samples location map of the area.

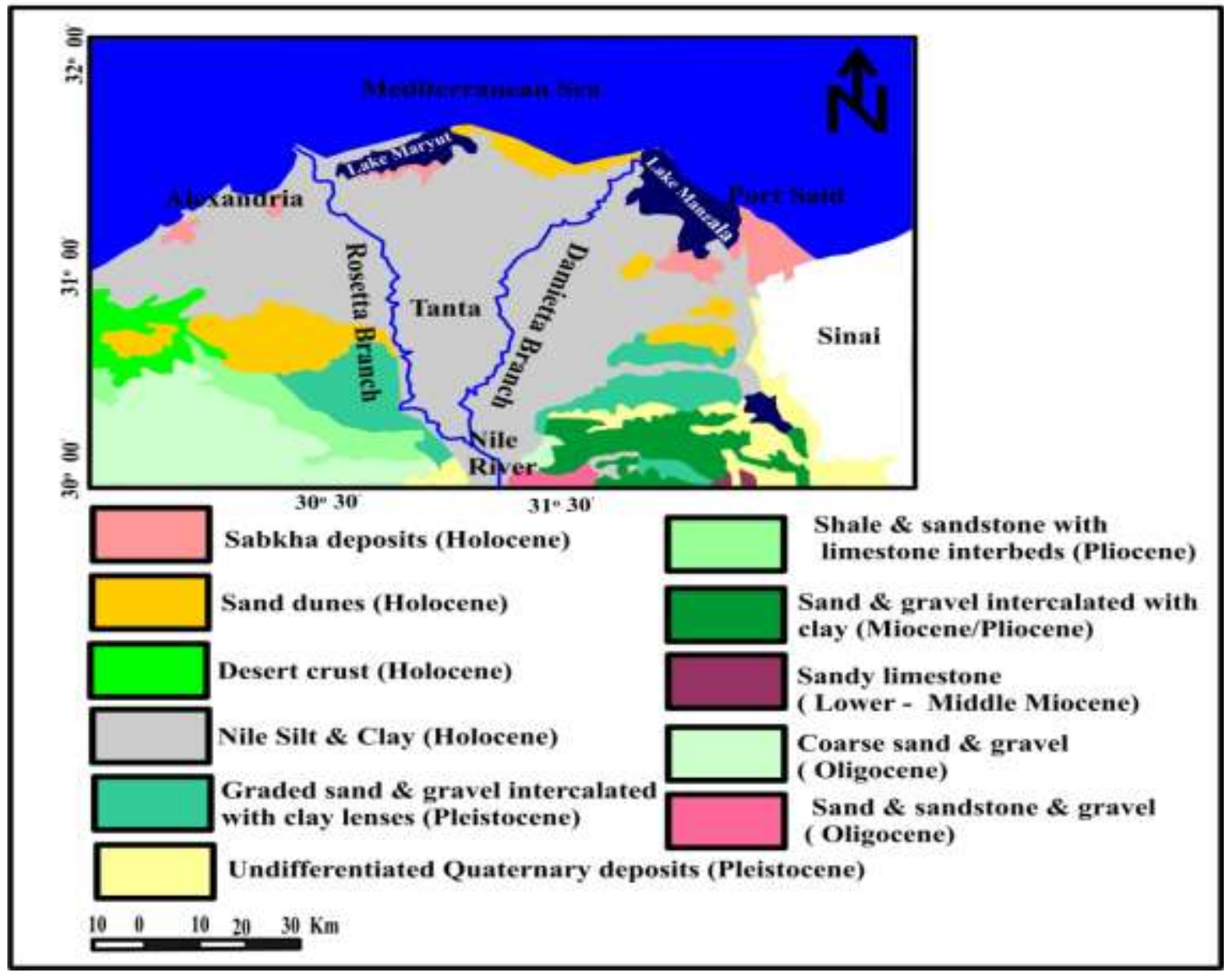

Fig. 2. Geologic map of the Nile River Delta (Based on CONOCO Coral 1987 and TM Satellite image, taken in 2003) 
It has a fertilized soil; many people live in this area. According to over population, there are many types of water pollution as industrial, agricultural pollution. There are many drainages and canals dissected the area beside the River Nile pass through the area and reach to the final station in the Mediterranean Sea (Rosetta downstream). Seawater intrusion and many types of water contamination affect the aquifer of the area. Therefore, the geoelectrical resistivity method has been applied. The concerned area is square, with a length of about fifty kilometers and a width of fifty kilometers, and an area of about two thousand five hundred square kilometers. In addition, the Nile River represented by the Rosetta Branch divides it from southeast to northwest directions (Fig. 1).

\subsection{Geological and hydrogeological settings}

Geologically, the Quaternary sediments comprising of Nile silt, clay, sandy clay, sands, and gravels cover the Nile Delta area (Fig. 2). Deep well drilling in this area provided the following very thick sedimentary sequences:

a) Holocene and Pleistocene sediments are characterized in Quaternary Time. Sand dunes, coastal deposits, sabkha deposits, and silty clay sediments cover the floodplain throughout the Holocene. Desert crusts, kurkar ridges, and graded sand and gravel containing the key water-bearing formation have all been considered during the Pleistocene period. The Quaternary aquifer is about 100 meters thick in Cairo, 1,000 meters thick on the coast, and zero meters thick east and west of the Nile Delta's fringes.

b) Pliocene, Miocene, Oligocene, Eocene, and Paleocene are Tertiary deposits, and Pliocene representing the lower boundary of the region's main water-bearing formation.

c) Miocene deposits (such as the Moghra) can be found up to 2,000 meters below the surface. Because of their limited contribution to groundwater in the Ile Delta area, the Oligocene and Eocene are of minor hydrogeological significance.

In the Nile Delta region (Fig. 3), there are three major groundwater aquifers with varying levels of importance for exploitation. From top to bottom, the Quaternary aquifer (semi-confined and unconfined), Pliocene aquifer, and Moghra aquifer are described as follows:

a) The Quaternary aquifer is the most important regional water-bearing formation. This aquifer is composed of Pleistocene graded sand and gravel that converts to fine and clayey facies as it moves north. It can be found in the Nile Delta floodplain. The Nile aquifer's clay cap is a semiconstricting layer with a thickness of 20 meters (as in the study area). In the central Delta, Pliocene marine clay underneath the aquifer, which wedges out toward the edges.

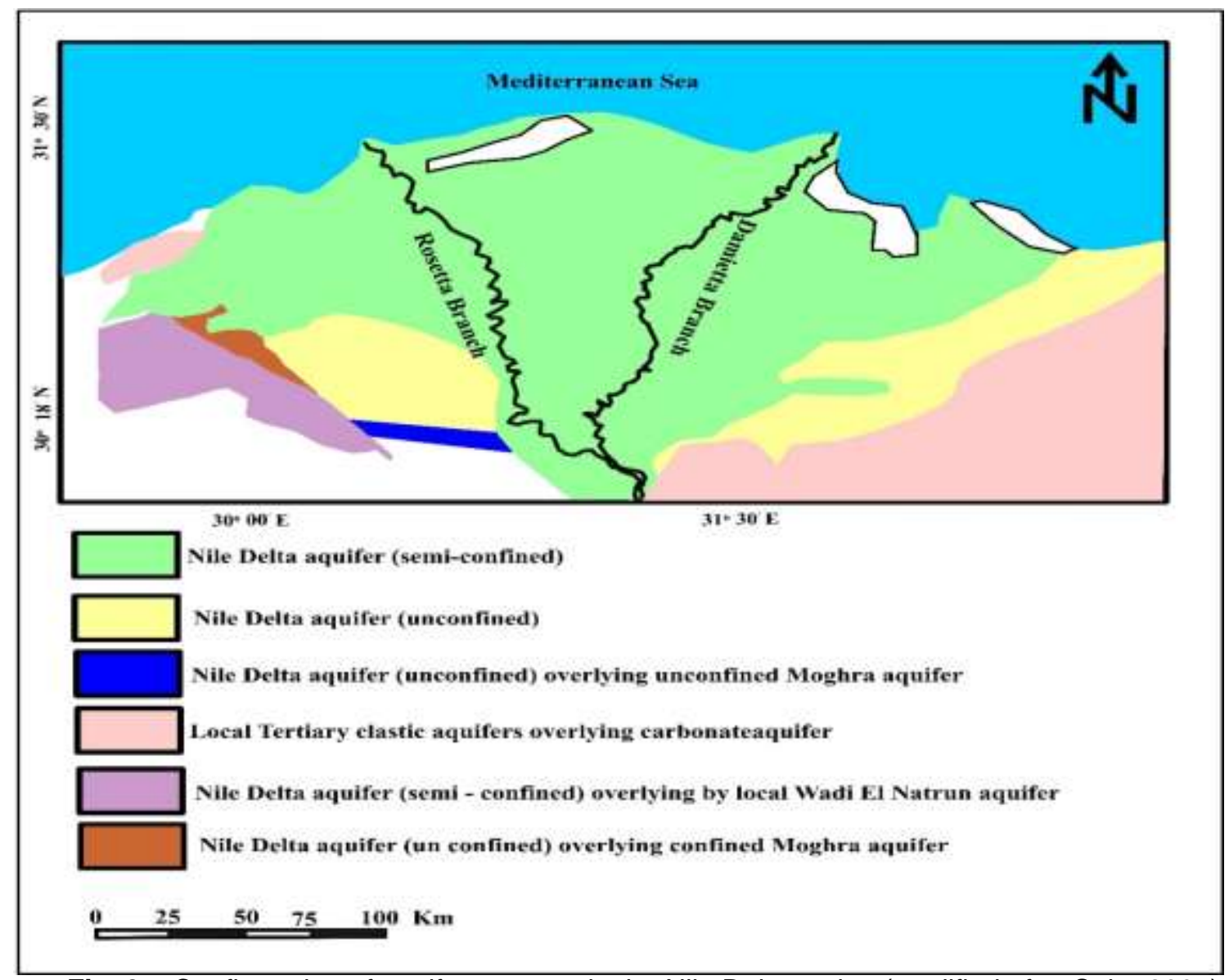

Fig. 3. Configuration of aquifer systems in the Nile Delta region (modified after Sakr, 2005). 
b) The Wadi Natrun Depression includes the Pliocene aquifer. It is classified as a local aquifer with low productivity. It is a multi-layered aquifer with alternating sand and clay layers. The aquifer is above the Moghra aquifer, but it is isolated from it by Lower Pliocene layers. Groundwater in Wadi Natrun Depression is drained into small lakes and ponds through a large number of infiltration areas. 70 million $\mathrm{m}^{3}$ of groundwater can be lost each year due to direct evaporation (RIGW, 1999).

c) The Moghra aquifer is situated in the Western Delta region and is composed mainly of Lower Miocene sand and gravel. It occupies an area of about $50,000 \mathrm{~km} 2$. It is located west of Wadi Al-Natrun and stretches all the way to the Qattara Depression. This aquifer is unconfined south of latitude $30^{\circ} \mathrm{N}$, but is confined in the north by Pliocene deposits and underlain by Oligocene rocks (basalts or shales). The aquifer's base slopes descend from ground level near Cairo to 100 meters above sea level near Borg El Arab. The aquifer groundwater flows westward toward the Qattara Depression, with a saturated thickness varying from 70 to 700 meters (RIGW/IWACO, 1990).

In general, the recharge that occurs from the Nile Delta to the Moghra and Pliocene aquifers is a secondary component of the flow between these aquifers. The Moghraa aquifer's groundwater salinity ranges from strong to brackish, with a maximum value of 7,000 ppm. Salinity levels rise from very low in Wadi El-Farigh to extremely high in the north and west. According to the Research Institute for Groundwater RIGW/IWACO (1990), aquifer potentiality ranges from low to moderate. The outflow from the Nile Delta aquifer toward the Moghra aquifer, which occurs along the western Nile Delta's fringes, is also estimated to be between 50 and $100 \mathrm{Mm}^{3} /$ year by RIGW/IWACO (1990).

\section{Data and methods}

\subsection{Vertical Electrical Sounding (VES)}

VES is an artificial electrical system used in the research area to calculate the resistivity of layers, with the embedded rocks and fluids, down to a segment of about $150 \mathrm{~m}$, using Schlumberger pattern. The outward resistivity values are calculated by the formula: $\rho a=K^{*} \Delta V / I$, where: where $\mathrm{K}$ is a geometric factor that is dependent on the electrode placement (Fig. 4). Twenty-six VESes were implemented in order to conduct the geoelectric resistivity survey, and their profiles were distributed throughout the area (Fig. 5). Eleric-T instrument was used to take field measurements (Fig. 6 ), with $A B / 2$ values ranging from $1 \mathrm{~m}$ to $500 \mathrm{~m}$. The field resistivity values are calculated by plotting the apparent resistivity values ( $\rho a)$ versus $(A B / 2)$ on a log- log graph paper. This is done to emphasize nearsurface resistivity variations while suppressing variation at greater depths, since the interpretation of the results is highly dependent on small resistivity variations at shallow depths.

Two suitable geoelectric software's were used to process the field resistivity data, allowing the user to construct true resistivity models that were equivalent to each sounding. As a result, the data was quantitatively analyzed using IPI2win in order to obtain a true layering model. The multi-layer models that resulted from these soundings (for example, Fig. 7) were used to conduct subsurface true resistivity contour sections, reduce the layers to five, and create a geoelectric model for the area. These five geoelectric layers can be converted into lithological and structural inferences by interpreting resistivities and thicknesses. Clay and sand as a surface layer (first layer), clay layer (second layer), sand layer (third layer), clay layer (fourth layer) and seawater intrusion zone (fifth layer) are the five layers defined in the region. As a result, iso-parametric maps and $2 \mathrm{D}$ and $3 \mathrm{D}$ cross sections have been created to show the lateral variations of geoelectrical data in the study region and to detect the characterization of seawater intrusion.

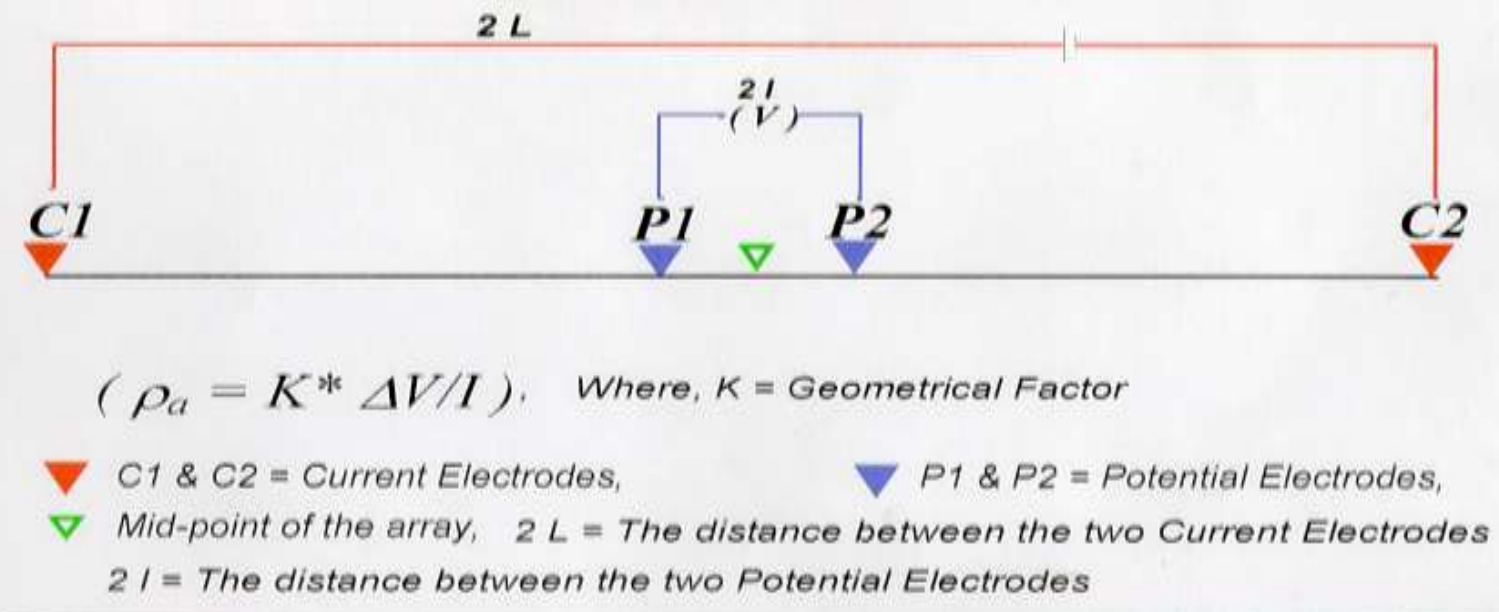

Fig. 4. Schematic diagram showing Schlumberger array geometry. 


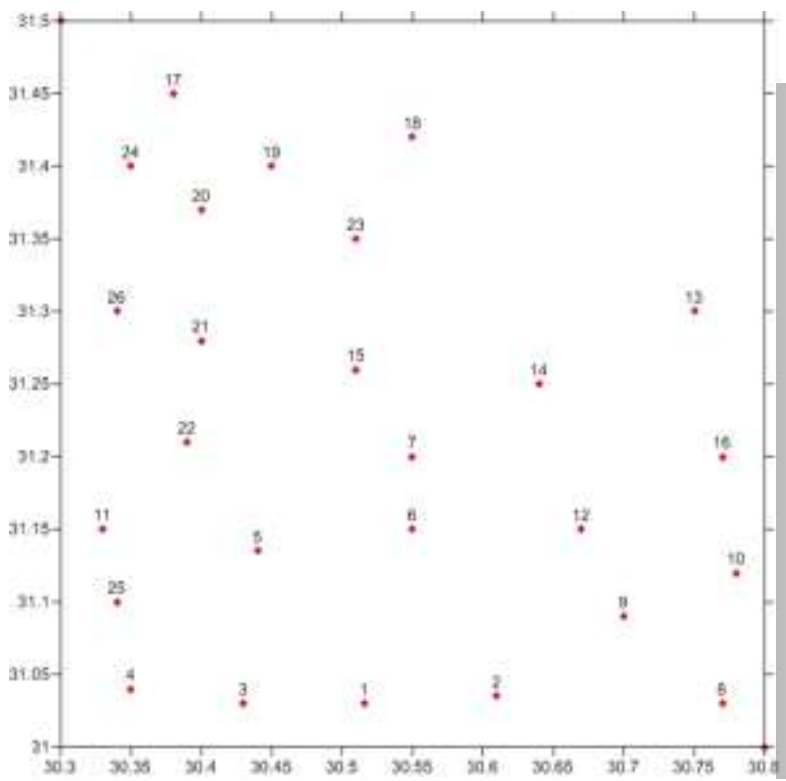

Fig. 5. Location Map of the Vertical electrical soundings

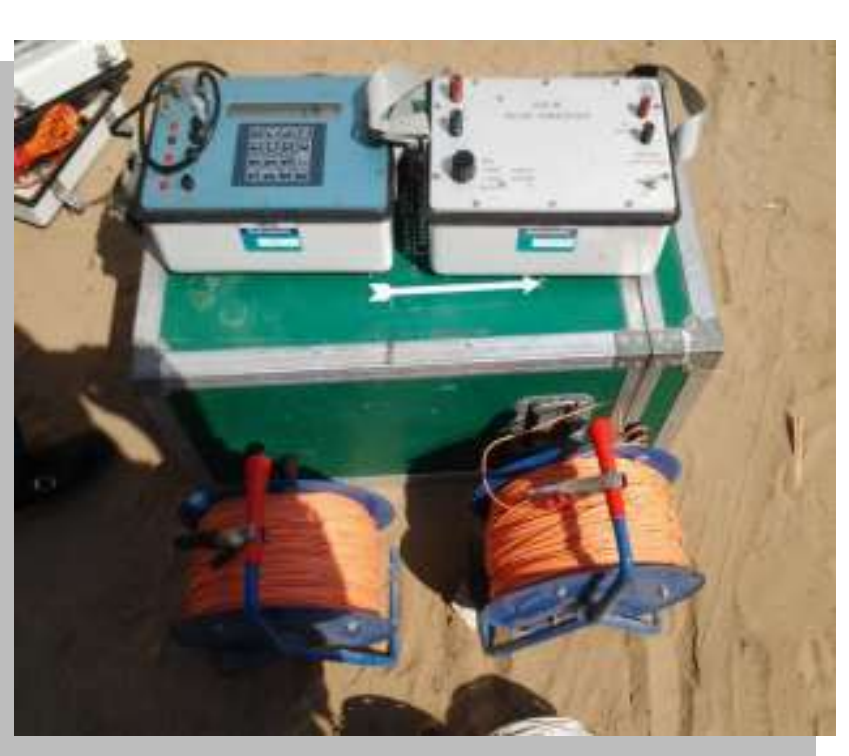

Fig. 6. Eleric-T resistivity meter, IRIS Instruments, France
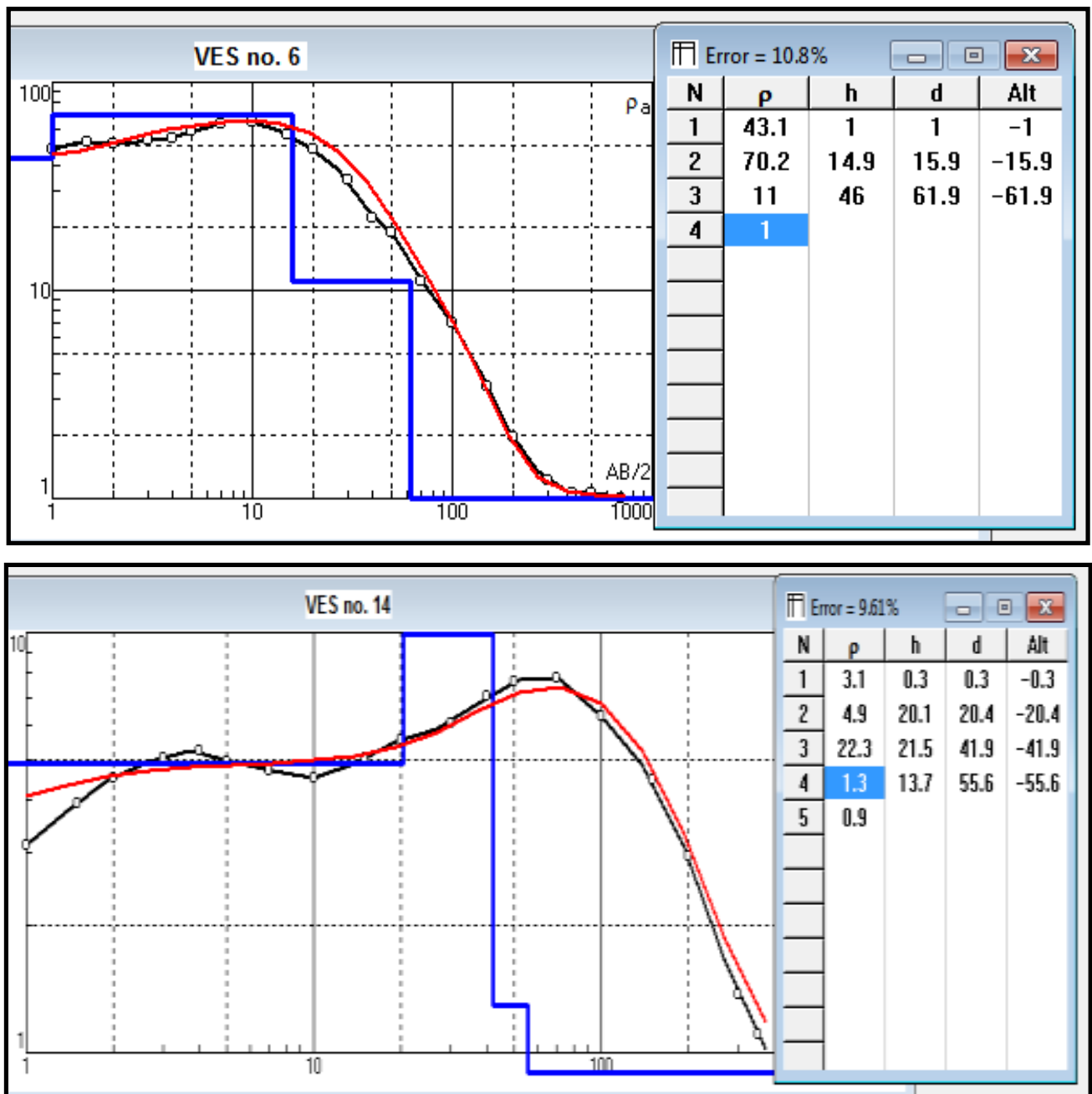

Fig. 7: Examples of interpreted Vertical electrical soundings No.6 and 14 in the area 


\subsection{Groundwater samples and analysis}

Twenty-six groundwater samples were taken from representative drilled wells in the area. Standard analytical methods were used for chemical analysis of the collected samples. $\mathrm{K}^{+}, \mathrm{Na}^{+}, \mathrm{Ca}^{2+}, \mathrm{Mg}^{2+}, \mathrm{Cl}^{-}, \mathrm{SO}_{4}{ }^{2-}, \mathrm{HCO}_{3}^{-}$, and $\mathrm{NO}_{3}{ }^{-}$ were measured using the standard methods in the laboratory. Electrical conductivity (EC) and $\mathrm{pH}$ of the studied samples were measured in the field. Correlation matrix of cation and anion of major elements were applied in this research. Moreover, Piper and Gibbs diagrams, (Piper 1944 and Gibbs 1970) were used for determining the different types of groundwater and the necessary processes affecting chemical composition of the groundwater. Moreover, origin and the groundwater quality of the studied samples were determined using the hydrochemical indices such as $\left(\mathrm{Mg} / \mathrm{Ca} ; \mathrm{Cl} / \mathrm{HCO}_{3}\right)$ and the cationic exchange value (CEV) which is $\{\mathrm{Cl}-(\mathrm{Na}+\mathrm{K})\} / \mathrm{Cl}$ (Nwankwoala and Udom 2011). Ionic relations between different ions were recognized using the excel worksheet for determining the different geochemical processes controlling the water chemistry.

\section{Water quality index (WQI)}

To assess the probability of the groundwater for drinking uses, an item called the water quality index is used for this purpose. Water quality index can be considered by conveying a weight for each chemical-parameter $(w i)$, then the relative weight $(W i)$ and quality rating scale $(q i)$ can be calculated for each water sample. Consequently, Srinivasamoorthy et al. (2008) assigned weighted values (wi) for $\mathrm{pH}$, TDS, EC, $\mathrm{Na}^{+}, \mathrm{K}^{+}, \mathrm{Ca}^{2+}, \mathrm{Mg}^{2+}, \mathrm{HCO}_{3}^{-}, \mathrm{Cl}^{-}$, $\mathrm{SO}_{4}{ }^{2-}$, and $\mathrm{NO}_{3}{ }^{-}$, that reflect the relative importance of the parameters which are involved in WQI (Table 1). The chemical parameters that have a great influence on the quality of water for drinking were assigned the highest values of weight of 4 and 5 such as TDS, Ec, $\mathrm{pH}$ and $\mathrm{NO}_{3}$. Other parameters were assigned lower weights, which reflect lesser importance on the quality of water (Kawo and Karuppannan, 2018). Secondly, the relative weight (Wi) was calculated using the following Eq. 1 (Brown et al. 1972; Ramya Priya and Elango 2018):

$$
W i=\frac{w i}{\sum_{1=1}^{\mathrm{n}} W \mathbf{i}} \quad \text { Eq. (1) }
$$

All concentrations in $\mathrm{mg} / \mathrm{l}$. Table 1 shows the values of the calculated Wi for different elements. The specified groundwater concentration, elements (ci), and drinking water quality $(\mathrm{Si})$ for the groundwater parameters (WHO 2011) were used to calculate qi presented in the following Eq. 2 (Brown et al. 1972; Ramya Priya and Elango 2018):

$$
q i=(C i \div S i) \times 100 \quad \text { Eq. (2) }
$$

Finally, using the measured values of qi and $\mathrm{Wi}$, the water quality index (WQI) was calculated using the following Eq. 3 (Brown et al. 1972; Ramya Priya and Elango 2018). WQI's spatial distribution map can also be shown in a GIS program using ArcMap.

$$
W Q I=\sum_{\mathrm{i}=1}^{\mathrm{n}} W i \times q i \text { Eq. (3) }
$$

\section{Results and discussion}

\subsection{Geophysical characteristics}

Based on Vertical Electrical Soundings data for the different electrical layers in the affected region, a number of geoelectrical maps have been developed. The following is a list of these layers, along with their descriptions and interpretations:

\section{A. The surface layer}

The recent deposits, deltaic deposits, and neo-Nile deposits are represented by this layer. It has a wide resistivity array, ranging on average from one to 52 Ohm.m. .Figure $(8 \quad a \& b)$ displays the true resistivity geoelectric and average thickness maps for this upper layer.

Table 1. Statistical descriptions of the measured physicochemical parameters.

\begin{tabular}{ccccccccc}
\hline Parameter & Unit & Minimum & Maximum & Mean & $\begin{array}{c}\text { Standard } \\
\text { Deviation }\end{array}$ & $\begin{array}{c}\text { WHO } \\
\mathbf{2 0 1 1}\end{array}$ & Weight(w) & $\mathbf{w}_{\mathbf{i}}$ \\
\hline $\mathbf{p H}$ & - & 7.19 & 7.99 & 7.56 & 0.27 & $6.5-8.5$ & 4 & 0.121212 \\
$\mathbf{E C}$ & $\mu \mathrm{S} / \mathrm{cm}$ & 538.12 & 38135.93 & 8413.25 & 11267.86 & 1000 & 4 & 0.121212 \\
$\mathbf{T D S}$ & $\mathrm{mg} / \mathrm{l}$ & 344.4 & 24407 & 5384.48 & 7211.43 & 500 & 5 & 0.151515 \\
$\mathbf{N a}$ & $\mathrm{mg} / \mathrm{l}$ & 30 & 7774 & 1518.69 & 2322.96 & 200 & 3 & 0.090909 \\
$\mathbf{C a}$ & $\mathrm{mg} / \mathrm{l}$ & 23.6 & 465 & 159.25 & 141.72 & 75 & 2 & 0.060606 \\
$\mathbf{M g}$ & $\mathrm{mg} / \mathrm{l}$ & 18 & 751 & 182.57 & 212.11 & 50 & 2 & 0.060606 \\
$\mathbf{K}$ & $\mathrm{mg} / \mathrm{l}$ & 3 & 265 & 26.34 & 53.34 & 12 & 1 & 0.030303 \\
$\mathbf{H C O}{ }_{3}$ & $\mathrm{mg} / \mathrm{l}$ & 73 & 4575 & 570.15 & 836.41 & 120 & 3 & 0.090909 \\
$\mathbf{C l}$ & $\mathrm{mg} / \mathrm{l}$ & 39 & 12173 & 2327.03 & 3565.57 & 250 & 1 & 0.030303 \\
$\mathbf{S O}_{\mathbf{4}}$ & $\mathrm{mg} / \mathrm{l}$ & 5.9 & 4358 & 600.41 & 1037.33 & 250 & 3 & 0.090909 \\
$\mathbf{N O}_{3}$ & $\mathrm{mg} / \mathrm{l}$ & 0.2 & 410 & 41.41 & 83.95 & 50 & 5 & 0.151515 \\
\hline
\end{tabular}


The highest true resistivity value (52 Ohm.m) is found in the northeast of the city, indicating the low salinity of dry deposits, while the lowest value (about one Ohm.m) is originate in the east. This is largely due to the soil type, which is characterized by clay materials and a high salinity content. This layer's average thickness varies from less than $0.3 \mathrm{~m}$ in the middle to east part of the region to more than $20.4 \mathrm{~m}$ in the south.

\section{B. The up clay layer}

Clay to sandy clay mainly makes up the bulk of this layer. It has a resistivity range of 0.5 to $23.8 \mathrm{Ohm} . \mathrm{m}$ throughout the region (Fig. 9a). The lowest resistivity value (0.5 Ohm.m) can be found in the northwest corner of the area, while the highest value $(23.8 \mathrm{Ohm} . \mathrm{m})$ can be create in the west. The layer thickness map (Fig. 9b), on the other hand, shows that it varies from 0.6 to $105.6 \mathrm{~m}$. The minimum thickness value $(0.6 \mathrm{~m})$ is located to the east, while the highest value $(105.6 \mathrm{~m})$ is identified to the southwest.

\section{The aquifer layers}

These layers are made up of medium to coarse sand, gravels, and fine sand with clay intercalation and are water saturated. All over the area, the layers have a resistivity range of 16.7 to 102 Ohm.m (Fig. 10a). The lowest resistivity value is located in the southern sections of the map, suggesting the presence of clay lenses in that direction. While the highest resistivity value is obtained in the southwestern parts of the area, which is due to the area's freshening water recharge from surface canals and irrigation activities. Figure (10b) shows a map of aquifer layers thickness distribution in the area. The aquifer has a minimum thickness of 6.2 meters in the northern sections and a maximum thickness of 49.5 meters in the southeast, with the aquifer thickness increasing towards the southeast.

\section{$D$. The down clay layer}

This is the fourth geoelectric layer, which is primarily clay-based. The average resistivity value varies between 1.1 and $8.1 \mathrm{Ohm}$ (Fig. 11a). The minimum value (1.1 ohm.m) is distributed in the west, while the maximum value (8.1 ohm.m) is distributed in the eastern area. The thickness distribution map of this layer (Fig. 12b) shows that the minimum thickness value is about $4.8 \mathrm{~m}$ in the northwestern direction of the region, while the maximum value is about $46 \mathrm{~m}$ in the central to south direction.

\section{$E$. The seawater intrusion limitations}

According to the used resistivity method in this analysis, the resistivity of brackish to saltwater zone is less than 1 Ohm.m (Fig. 12a). The depth of seawater penetration varies from 2 to 61.9 meters above sea level (Fig. 12b). Due to seawater-intrusion, the minimum depth in northern sections is about 2 meters. The maximum depth (61.9 meter) are showed inside the central parts. Within the south and southeast of the area, the applied resistivity method failed to reach the seawater intrusion zone.

In expansion, 2D and 3D geoelectrical cross sections have been developed within the concerned area utilizing the commercial Rockwork Software (Rockwork, 2004), to demonstrate the lithological and varieties of the over outlined five geoelectric-layers along these paths. The 2D cross section comprises three patterns $A-a, B-b$ and $C$ $C$ as found in Figure (13). The primary one (A - a) passes through the VESes, in west portion of the area (south-north course) whereas the moment $(B-b)$ runs parallel to the past cross-section and through the eastern VESes, (southnorth course). The final one $(C-c)$ cross the past two sections and pass within the mid the area (west-east course). These sections have been utilized to demonstrate their stratigraphic and basic suggestions and their part in finding the aquifer and water saltiness variety over the region. In any case, the western geoelectric section (A-a) appear that, the resistivity expanded within the south path of the area and diminished towards the north path. The eastern $\mathrm{B}-\mathrm{b}$ cross-section outline the higher resistivity values where the fresh water energize from the Rosetta branch of Nile River. This fresh water impact diminishes towards the north heading due to the seawater invasion influence in this direction (Fig. 13).
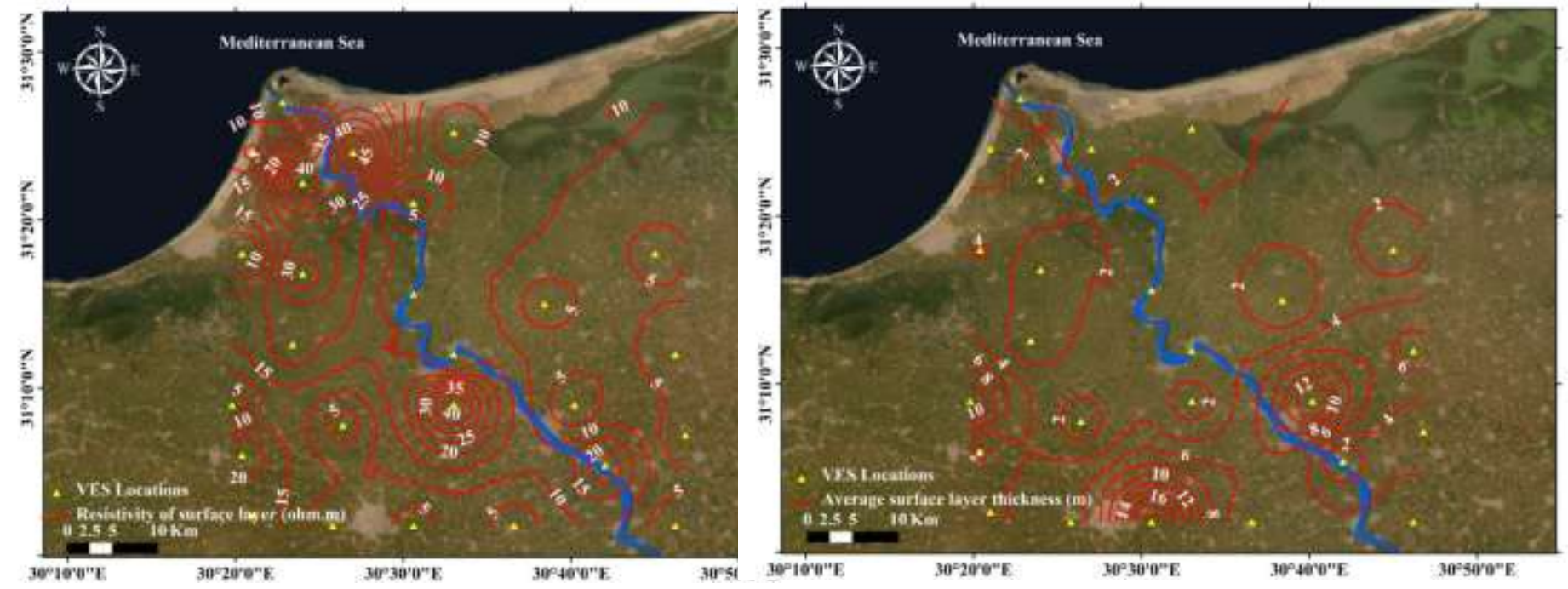

Fig. 8. The true resistivity and average thickness distribution maps of surface layer 

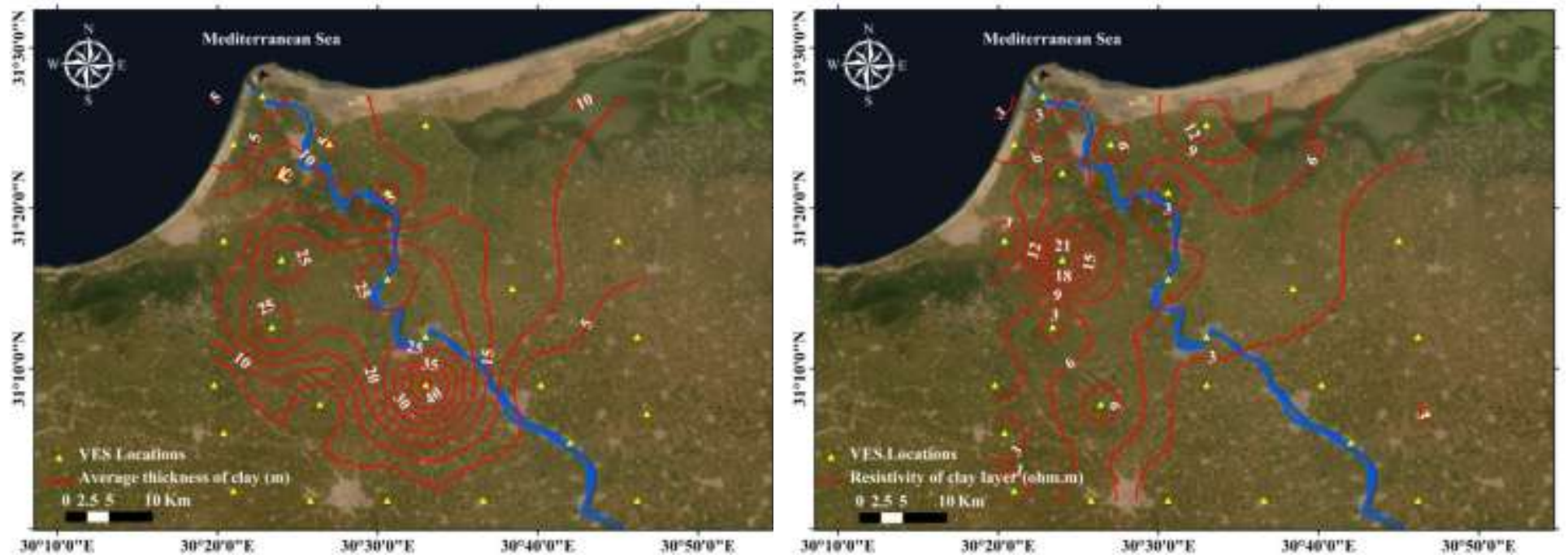

Fig. 9. The true resistivity and average thickness distribution maps of clay (up) layer.
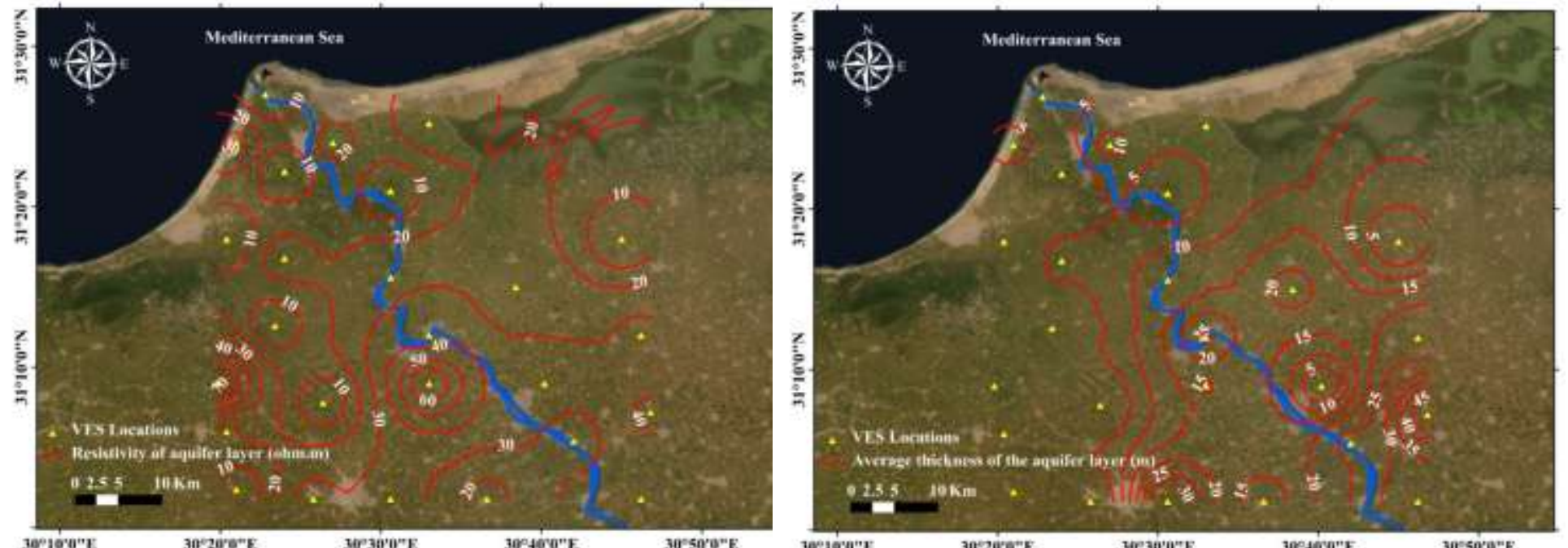

Fig. 10. The true resistivity and average thickness distribution maps of the aquifer layer
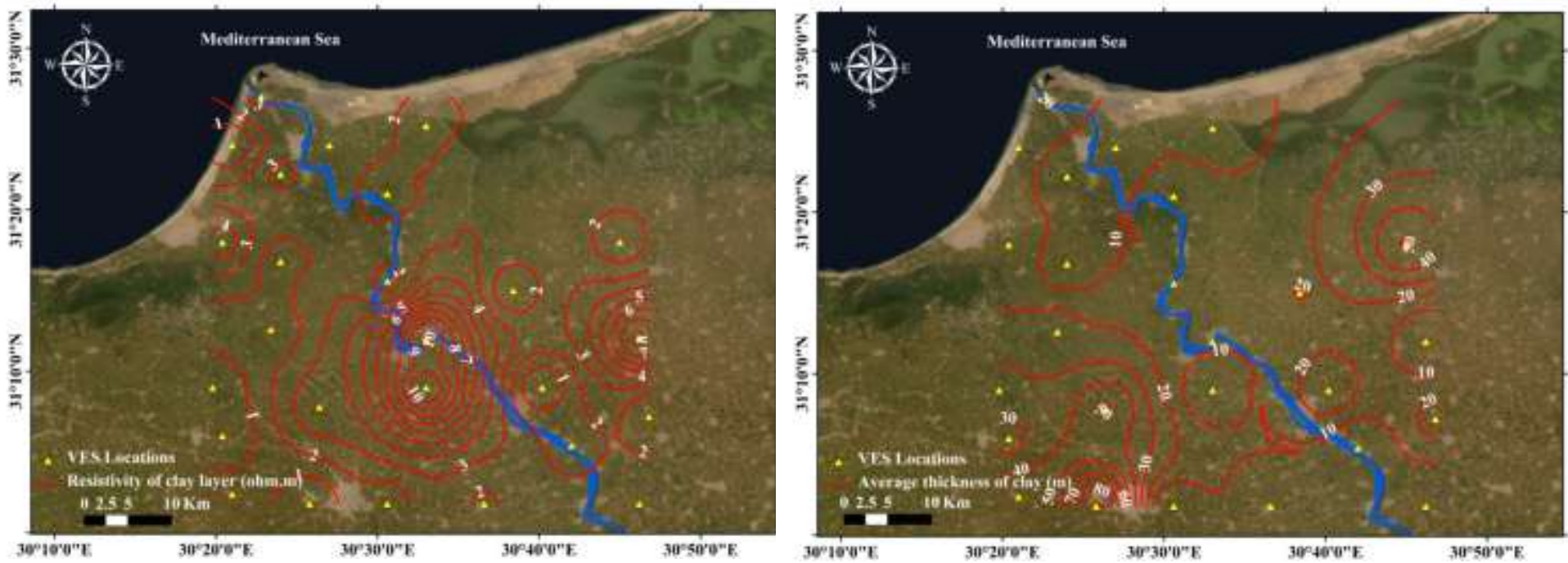

Fig. 11. The true resistivity and average thickness distribution maps of clay (down) layer 

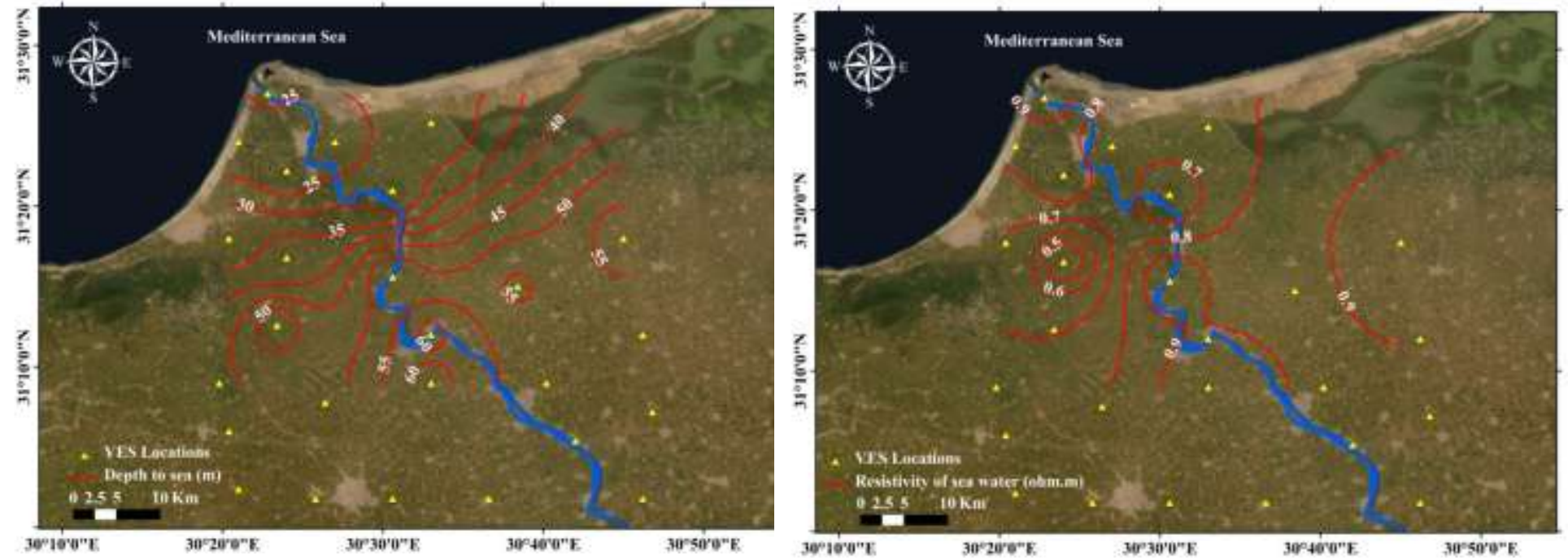

Fig. 12. The true resistivity and average depth distribution maps of seawater intrusion zone.

The final one $(C-C)$ segment has the higher resistivity esteem to the west heading and diminishes towards the east heading to the Burullus Lake, where the seawater intrusion impact moreover. In common, the south and west parts have higher resistivity values where the fresh water recharge from the Nile, whereas the decreased resistivity values to the north and east parts where the saline water interruption from the Mediterranean Sea and Burullus Lake.

Due to bland surface of the region, no prominent topographic adjustment was been required. In expansion, the delivered inverse-model resistivity sector of twenty six profiles discover an event of 5 layers, dependent on the stratigraphy and supplementary truncation (Griffiths and Barker, 1993). From top to bottom, the layers are: surface deposits of sands and clay (recent); clay layer (recent); sand layer (Pleistocene) for the third aquifer layer; clay layer (Pleistocene) for the fourth layer; and seawater penetration zone for the fifth layer. Their water contents include saltwater intrusion, brackish transitional water, and aquifer fresh water. Water occurrences, types, and arrangements within the evaluated sectors are the key issue during this powerful electrical method (Tripp et al., 1984). Seawater infiltrates the surface zone in some situations, followed by brackish water, and then fresh water at depth. At other times, the fresh water zone can start at the surface, move to brackish water zone, and finally end at depth with the saline water zone. Salt and fresh water can be interchangeable laterally at times, as isolated islands at surface and deeper zones (Sharma, 1997).

The true resistivities and thicknesses at all sounding points are interpolated to construct solid geophysical models in 3D of the data set (Fig. 14). Because of the dry surface layer, this model represents a high resistivity zone in shallow depths in southern part of the area, with an average of about 30 to $73 \mathrm{Ohm} . \mathrm{m}$. This value decreases with depth until it reaches the brackish water's low resistivity zone. This model is designed to display only the thickness and depths of this resistivity a depth of nearly 80 meters in the southern parts, beginning at the land surface. The depth decreases (nearly $0 \mathrm{~m}$ ) towards to north of the area, where the seawater sector, which can be considered as the study area's groundwater aquifer. This resistivity averages at seawater intrusion effect occurs.

\subsection{Hydrochemistry of groundwater Physicochemical parameters}

Physiochemical parameters are important in water quality assessments and are regarded as an essential tool for determining the nature of water chemistry and important control mechanisms. The physicochemical parameters of groundwater samples were statistically were been defined as shown in Table (1). TDS values ranged from 344.4 to $24407 \mathrm{mg} / \mathrm{L}$, with a mean value of $5384.48 \mathrm{mg} / \mathrm{L}$, and were associated with EC values that ranged from 538.12 to $38135.93 \mu \mathrm{S} / \mathrm{cm}$ with a mean value of $8413.25 \mu \mathrm{S} / \mathrm{cm}$. The concentrations of cation and anion of $\mathrm{Na}^{+}, \mathrm{K}^{+}, \mathrm{Mg}^{+2}, \mathrm{Ca}^{+2}$, $\mathrm{Cl}^{-}, \mathrm{SO}_{4}{ }^{2-}$, and $\mathrm{NO}_{3}{ }^{-}$showed mean values of 1518.69 , 26.34, 182.57, 159.25, 2327.03, 600.41, and $41.41 \mathrm{mg} / \mathrm{L}$, respectively.

\section{Correlation matrix}

The constructed hydrochemical parameter correlation matrix indicates an overly positive correlation between EC and TDS of the analyzed water samples (Table 2). Actually, electric conductivity increases with increasing the concentration of dissolved constituents in water. The EC and TDS also display very positive relationships with $\mathrm{Na}^{+}$, $\mathrm{Ca}^{2+}, \mathrm{Mg}^{2+}, \mathrm{Cl}^{-}, \mathrm{SO}_{4}^{2-}, \mathrm{HCO}_{3}^{-}$and $\mathrm{K}^{+}$, indicating that they are dedicated to essential geochemical methods through mineralogical impact (Tay et al. 2017). Evaporate dissolution is responsible for the heavy correlation between $\mathrm{Na}^{+}$and $\mathrm{Cl}^{-}(0.98)$ and a high correlation between $\mathrm{Mg}^{2+}$ and $\mathrm{Cl}^{-}(0.82)$. The relatively high correlations between $\mathrm{Cl}^{-}$and $\mathrm{SO}_{4}^{2-}(r=0.60)$ and $\mathrm{Mg}^{2+}$ and $\mathrm{Cl}^{-}(r=0.82)$ represent the area's agricultural activity.

\section{Geochemical Facies and Controlling Mechanisms}

With respect to the predominant cations and anions of the analyzed groundwater samples, Piper's trilinear diagram was recognized (Fig. 15). The analyzed samples chemical composition revealed that, there are mainly three types of water represented by, there are three water types presented by $\mathrm{Na}-\mathrm{Cl}-\mathrm{SO}_{4}, \mathrm{Ca}-\mathrm{Mg}-\mathrm{Cl}-\mathrm{SO}_{4}$ and $\mathrm{Ca}-\mathrm{Mg}$ alkalinity in the region. 


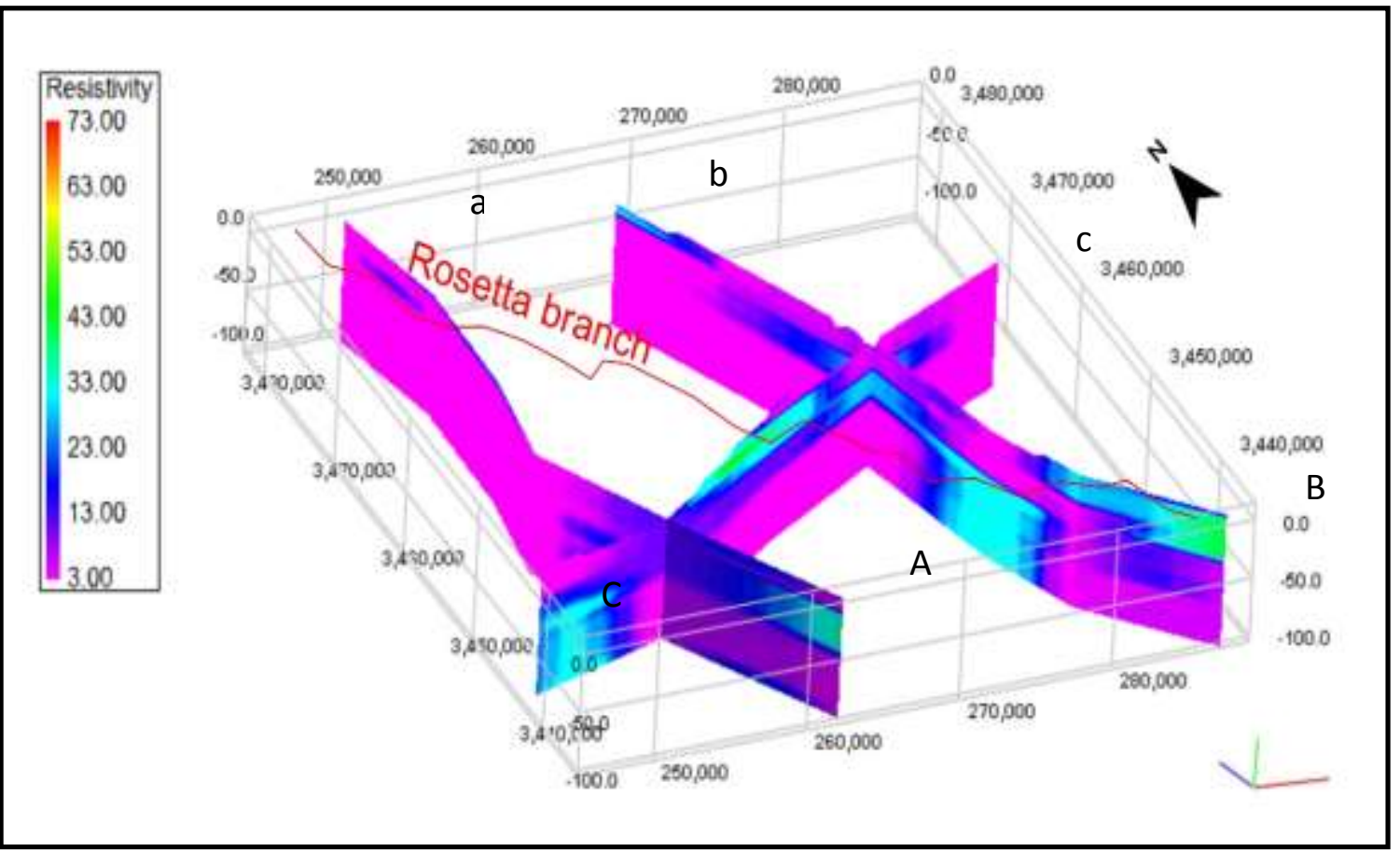

Fig. 13: The 2D cross sections (two runs $S-N$ and one runs $E-W$ ) of the area.

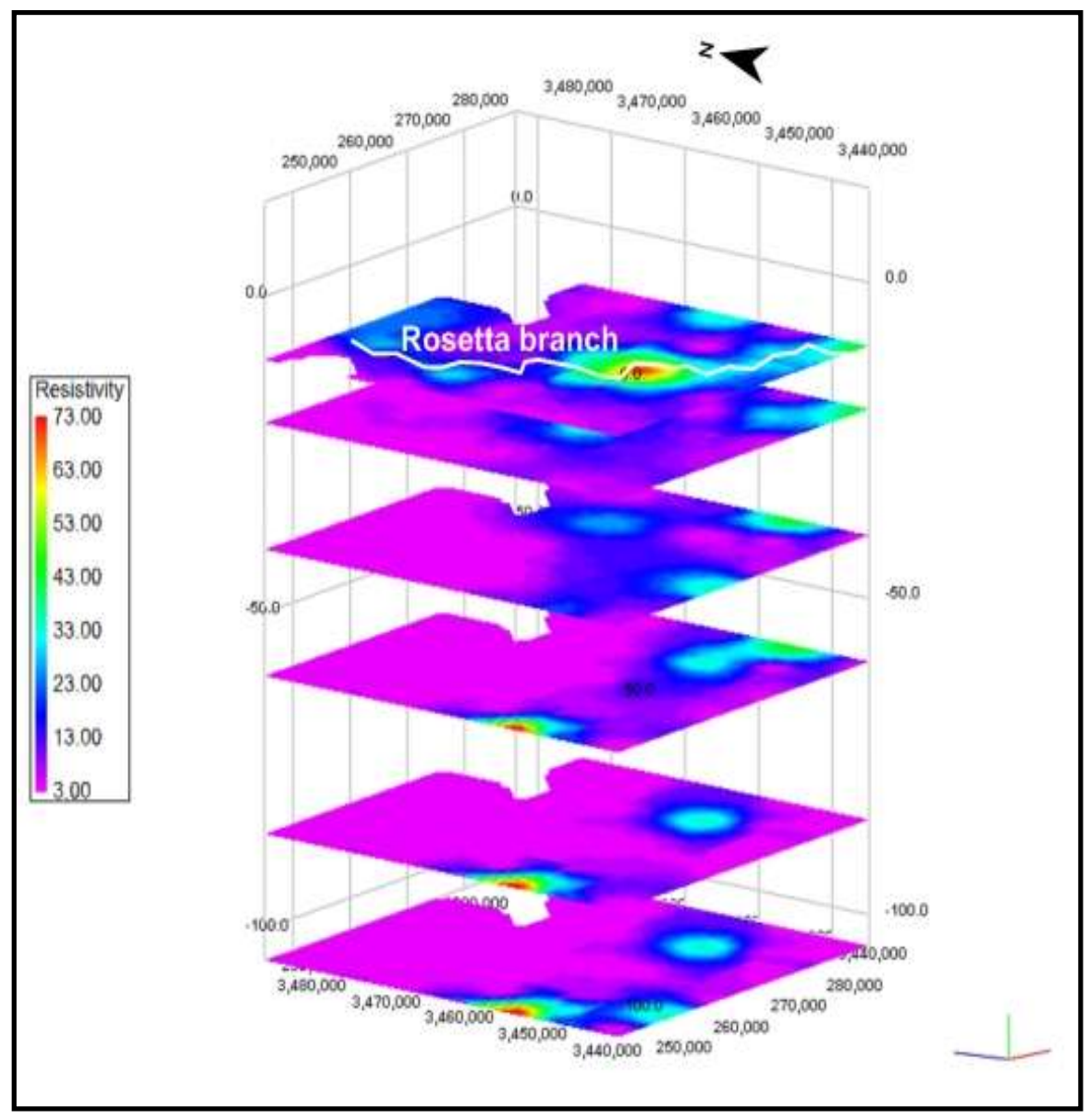

Fig. 14: 3D model slices of geoelectrical layers resistivity and depths distribution in the area. 
The key driving processes that regulate groundwater geochemistry can be identified using Gibb's diagram, which plots TDS vs. the proportions $(\mathrm{Na}+\mathrm{K}) /(\mathrm{Na}+\mathrm{K}+\mathrm{Ca})$ and $\mathrm{Cl} /(\mathrm{Cl}+$ alkalinity $)$. The groundwater points were clearly identified as being in the rock dominance and evaporation areas (Fig. 16).

A Chadha digram was used in this study to classify groundwater samples into different water types and to describe the hydrochemical processes that govern mineralization within the aquifer system (Chadha 1999). This diagram may have been a changed form of the Piper diagram (Piper 1944) and the expanded Durov diagram
(Durov 1948). The two equilateral triangles in the piper diagram, on the other hand, were neglected (Chadha 1999).The studied groundwater samples of the studied region fall within the field 3 of Chadha's diagram, indicating $\mathrm{Na}-\mathrm{K}-\mathrm{Cl}-\mathrm{SO} 4$ water type (Fig. 17). In this field, strong acidic anions $\left(\mathrm{Cl}^{-}\right.$and $\left.\mathrm{SO}_{4}{ }^{2-}\right)$ exceed the number of weak acidic anions $\left(\mathrm{HCO}_{3}{ }^{-}\right.$and $\left.\mathrm{CO}_{3}{ }^{2-}\right)$. Alkalis $\left(\mathrm{Na}^{+}\right.$and $\left.\mathrm{K}^{+}\right)$are also more abundant than alkaline earths $\left(\mathrm{Ca}^{2+}\right.$ and $\left.\mathrm{Mg}^{2+}\right)$. This water form illustrates the impact of seawater intrusion on groundwater chemistry, as evidenced by geoelectrical resistivity results in the region (Figures 13 and 14).

Table 2. Correlation matrix for different water parameters at the study area

\begin{tabular}{|c|c|c|c|c|c|c|c|c|c|c|c|}
\hline & $E c(m S)$ & $T D S(p p m)$ & $p H$ & $K$ & $\mathrm{Na}$ & $M g$ & $\mathrm{Ca}$ & $\mathrm{NO}_{3}^{--}$ & $C L^{-}$ & $\mathrm{SO}_{4}{ }^{2-}$ & $\mathrm{HCO}_{3}^{-}$ \\
\hline Ec $(\mathrm{mS})$ & 1 & & & & & & & & & & \\
\hline TDS (ppm) & 0.939087 & 1 & & & & & & & & & \\
\hline $\mathrm{pH}$ & -0.24741 & -0.17582 & 1 & & & & & & & & \\
\hline K & 0.774105 & 0.745997 & -0.31936 & 1 & & & & & & & \\
\hline $\mathrm{Na}$ & 0.86913 & 0.83784 & -0.31108 & 0.697078 & 1 & & & & & & \\
\hline $\mathrm{Mg}$ & 0.920208 & 0.851091 & -0.16709 & 0.550548 & 0.787954 & 1 & & & & & \\
\hline $\mathrm{Ca}$ & 0.87177 & 0.826839 & -0.18686 & 0.545339 & 0.675582 & 0.843205 & 1 & & & & \\
\hline $\mathrm{NO}_{3}^{--}$ & -0.00016 & 0.036793 & 0.113583 & 0.11238 & 0.229429 & -0.08227 & -0.08258 & 1 & & & \\
\hline $\mathrm{CL}^{-}$ & 0.882817 & 0.824599 & -0.34385 & 0.729072 & 0.986728 & 0.823423 & 0.691401 & 0.1612 & 1 & & \\
\hline $\mathrm{SO}_{4}^{--}$ & 0.746925 & 0.780322 & -0.1811 & 0.512834 & 0.658069 & 0.619188 & 0.832287 & 0.106404 & 0.607587 & 1 & \\
\hline $\mathrm{HCO}_{3}^{-}$ & 0.43918 & 0.455368 & 0.218468 & 0.05722 & 0.370189 & 0.526996 & 0.276552 & 0.038963 & 0.322653 & 0.093464 & 1 \\
\hline
\end{tabular}

Note: Numbers in bold shows good correlation

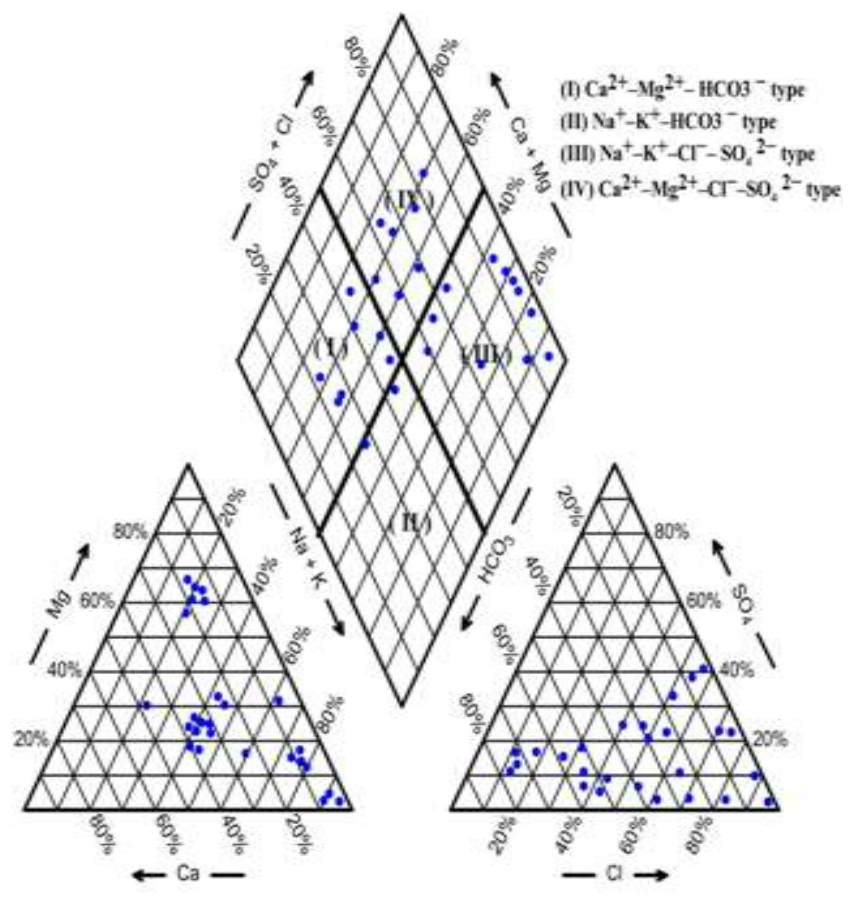

Fig. 15: Piper trilinear diagram for the groundwater samples in the study area.

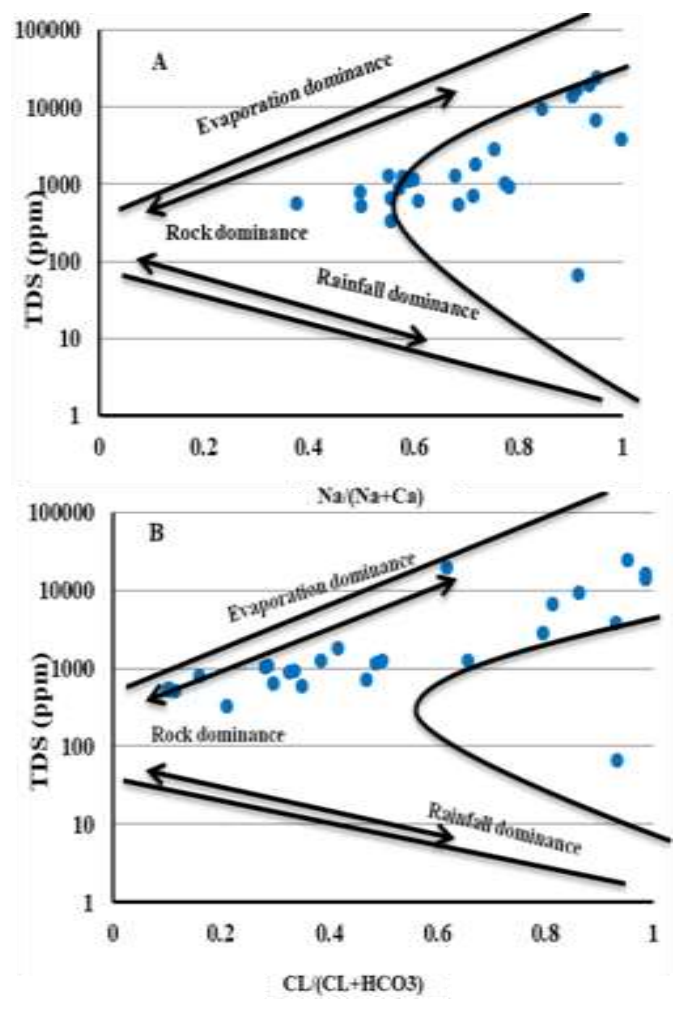

Fig. 16: Geochemical controlling mechanisms (Gibbs diagram). 

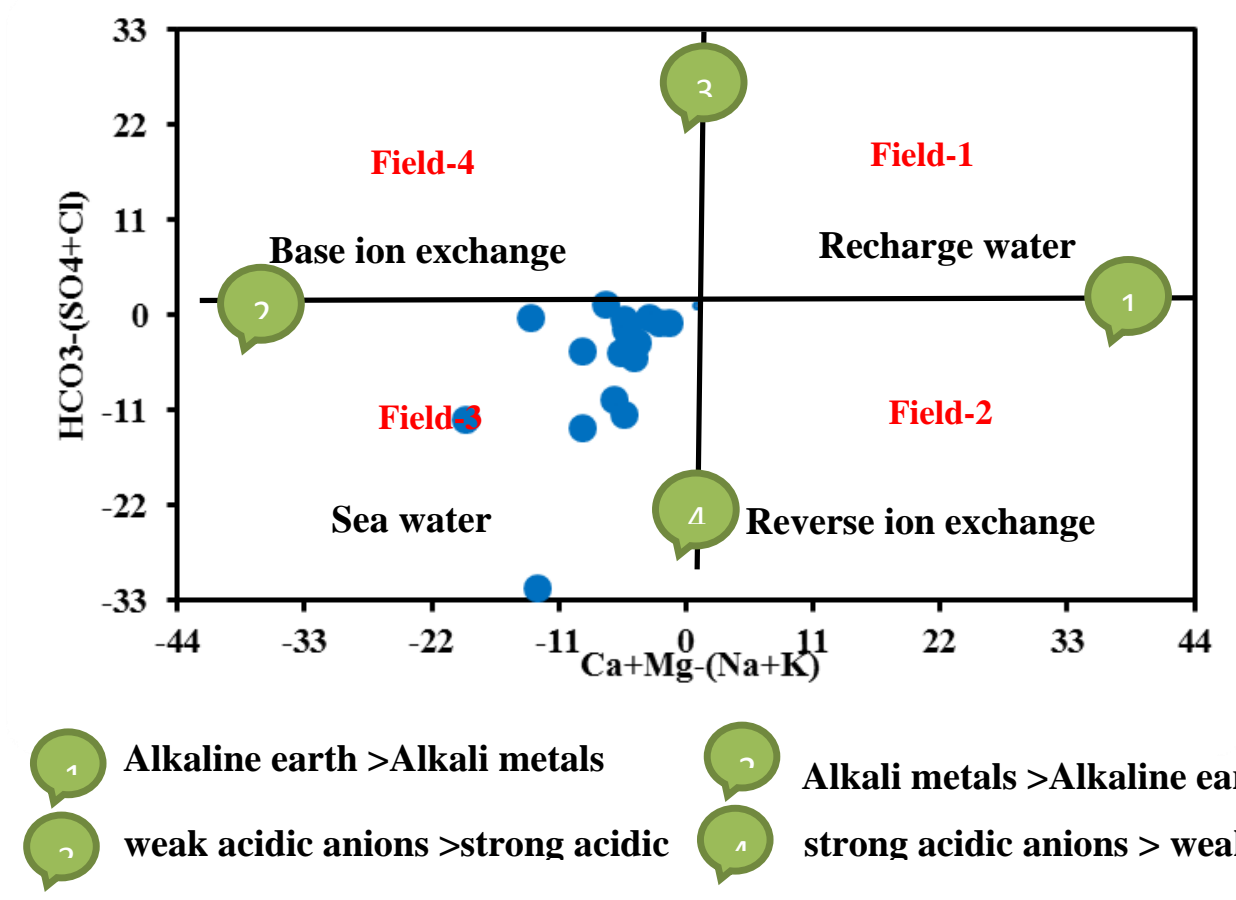

Alkaline earth >Alkali metals

weak acidic anions >strong acidic

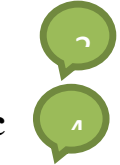

Alkali metals >Alkaline earth

strong acidic anions $>$ weak acidic

Fig. 17: Chadha diagram showing the water type of the groundwater samples.

Table 3. Statistics of the hydrochemical indices for determining the groundwater origin.

\begin{tabular}{c|c|c|c|c}
\hline Parameter & Minimum & Maximum & Average & Standard deviation \\
\hline $\mathrm{Mg} / \mathrm{Ca}$ & 0.31 & 14.09 & 14.45 & 2.79 \\
$\mathrm{Cl} / \mathrm{HCO}_{3}$ & 0.19 & 125 & 1.53 & 32.02 \\
$\mathrm{CEV}$ & -2.58 & 0.60 & -0.27 & 0.65 \\
\hline
\end{tabular}

\section{Groundwater origin}

$\mathrm{Cl} / \mathrm{HCO}_{3}$ parameter in the water samples analyzed ranged from 0.194 to 125 , with an average of 14.45 , representing an inland-origin for all groundwater points in the area. The $\mathrm{Mg} / \mathrm{Ca}$ percentage varies between 0.31 and 14.09, with a mean value of 2.37 (Table 3). Groundwater of marine origin has $\mathrm{Mg} / \mathrm{Ca}$ values close to 3.7 (Nessim et al. 2015), but most of the samples tested have $\mathrm{Mg} / \mathrm{Ca}$ values less than 3. According to Custodio (1983), a CEV rate close to zero, whether negative or positive, suggests low salt inland waters, while seawater should have a CEV value between +1.2 and +1.3 . Accordingly, CEV values for the studied groundwater samples range from 2.58 to 0.60 , with a mean value of 0.27 , indicating an inland water source (Table 3).

\section{Estimation of ionic relationships in groundwater samples}

Ionic relationships are crucial for defining the origin of solutes and the various processes that form groundwater chemical composition. In arid and semi-arid areas, salinity and saline intrusion mechanisms can be calculated using the Na-Cl correlation (Sami 1992). Positive relationship between $\mathrm{Na}^{+}$and $\mathrm{Cl}^{-}$suggesting that the key cause of $\mathrm{Cl}^{-}$ and $\mathrm{Na}^{+}$is halite dissolution (Fig. 18a). Fisher and Mullican (1997) established a relationship between $\mathrm{Ca}+$ $\mathrm{Mg}-\left(\mathrm{SO}_{4}+\mathrm{CO}_{3}+\mathrm{HCO}_{3}\right)$ and $\mathrm{Na}-\mathrm{Cl}$ to explain the source of excess Na. Results of this relation show a linear relationship $\left(R^{2}=0.20\right)$ with slope of -0.76 (Fig. 18b). The low correlation coefficient suggests that the reverse ion exchange mechanism is affecting the groundwater chemical composition. The reverse ion exchange is an important process affecting the chemical constituents of groundwater, as shown by a relationship between $\mathrm{Na}^{+}$and $\mathrm{Ca}+\mathrm{Mg}$ (Fig. 18c). The presence of gypsum mineral is reflected in the positive relationship between $\mathrm{Ca}$ and $\mathrm{SO}_{4}$ (Fig. 4d). The relationship in (Fig. 18e) shows that silicate weathering is an important factor in determining groundwater composition in the area. Finally, weathering of Glauber's salt $\left(\mathrm{Na}_{2} \mathrm{SO}_{4}\right)$ is another source of excess $\mathrm{Na}^{+}$, as shown by a positive relationship between $\mathrm{Na}^{+}$and $\mathrm{SO}_{4}{ }^{2-}$ (Fig. 18f).

All of these hydrochemical parameters support the groundwater's inland origin, but the observed rise in salinity, as well as changes in water types, hydrochemical indices, and ionic relationships, are due to intrusion from seawater to a relatively high distance south of the area.

\section{Water Quality Indices}

Many of irrigation and drains canals pass through the area (Fig. 1). The main irrigation canal is the River Nile (Rosetta branch). These trenches influence the groundwater flow system, surface water level variability, and flow direction; they have caused water quality 
changes. The exchange between surface water and groundwater flow system is somewhat complicated and seasonally variable. The current surface water canals have mostly penetrated through the Quaternary sediments and hydraulically interacted with the shallow aquifer (Salem and Osman, 2016).

Finally, the quality of drinking groundwater in the concerned region can be determined based on all of these chemical characteristics of groundwater. As a result, Table 4 contains the statistical explanations of Drinking Water Quality Indices (DWQI). The DWQI scores ranged from
61.05 to 2019.75 , with 447.53 being the average. 3.85 percent of the groundwater samples obtained were fell in the poor water category, with 11.54 percent of samples falling into the very poor water category and 87.86 percent of samples falling into the unsafe for drinking water categories. As shown in Figure 19, the spatial variation of the Drinking Water Quality Index DWQI in the concerned region is defined using an Arc map in a GIS environment. The majority of the studied groundwater wells are unsuitable for drinking due to the effects of saltwater intrusion, which extends to around $50 \mathrm{~km}$ inland (Fig. 19).
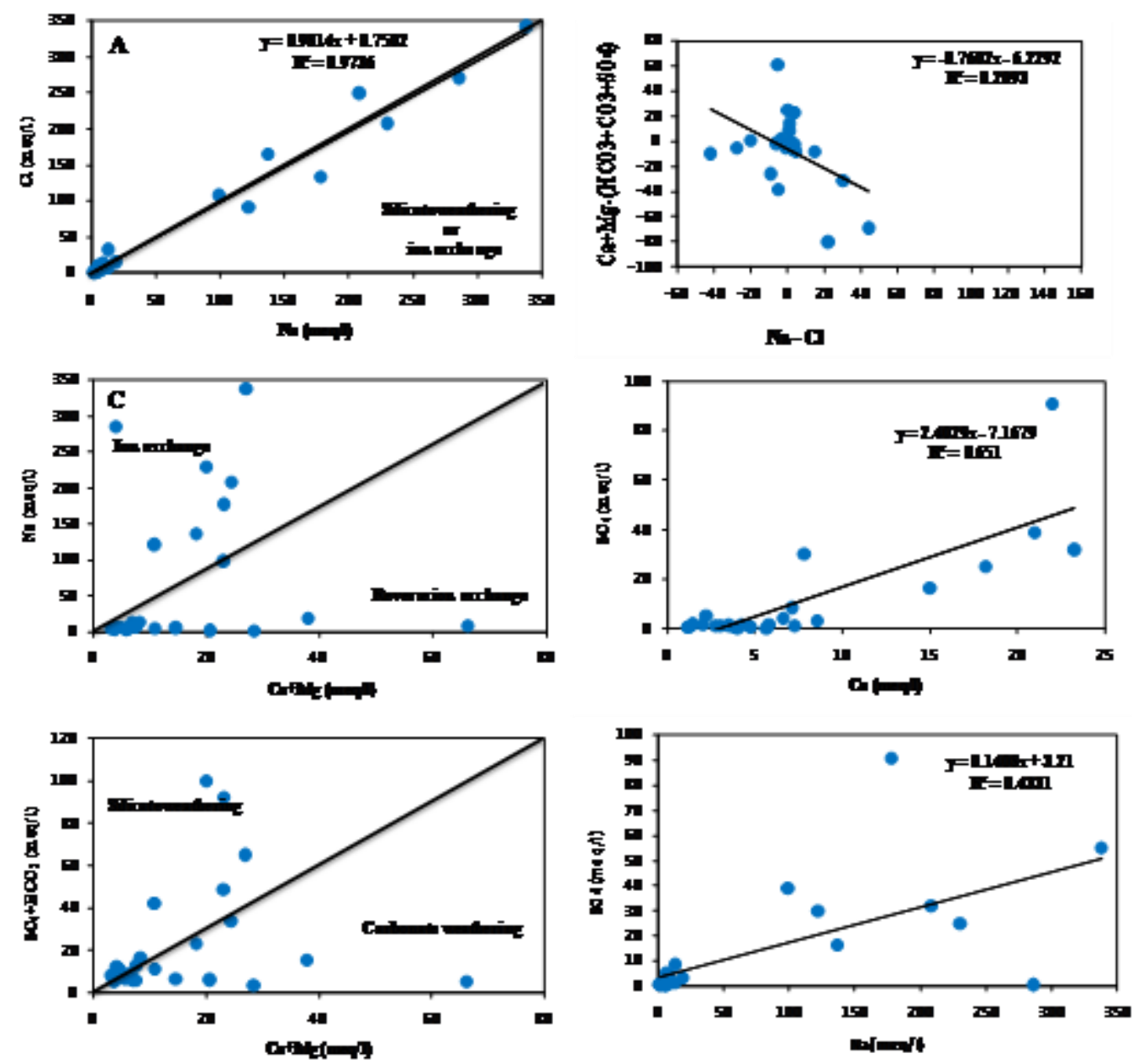

Fig. 18: Major cations and anions relationships with ionic ratios.

Table 4. Drinking water quality Index for the groundwater samples in the area.

\begin{tabular}{cccccc}
\hline Parameters & Ranges & Water class & Percent of samples & Formula & Source \\
\hline & $0-25$ & Excellent water & - & & \\
& $26-50$ & Good water & - & & \\
DWQI & $51-75$ & Poor water & $3.85 \%$ (1 samples) & DWQI= $\sum_{i=1}^{\text {n }}$ qiWi & $\begin{array}{c}\text { Chatterji and } \\
\text { Raziuddin } \\
2002\end{array}$ \\
& $76-100$ & Very Poor water & $11.54 \%$ (3 samples) & & \\
& $>100$ & $\begin{array}{c}\text { Unsuitable water } \\
\text { for drinking }\end{array}$ & $87.86 \%$ (22 samples) & & \\
\hline
\end{tabular}




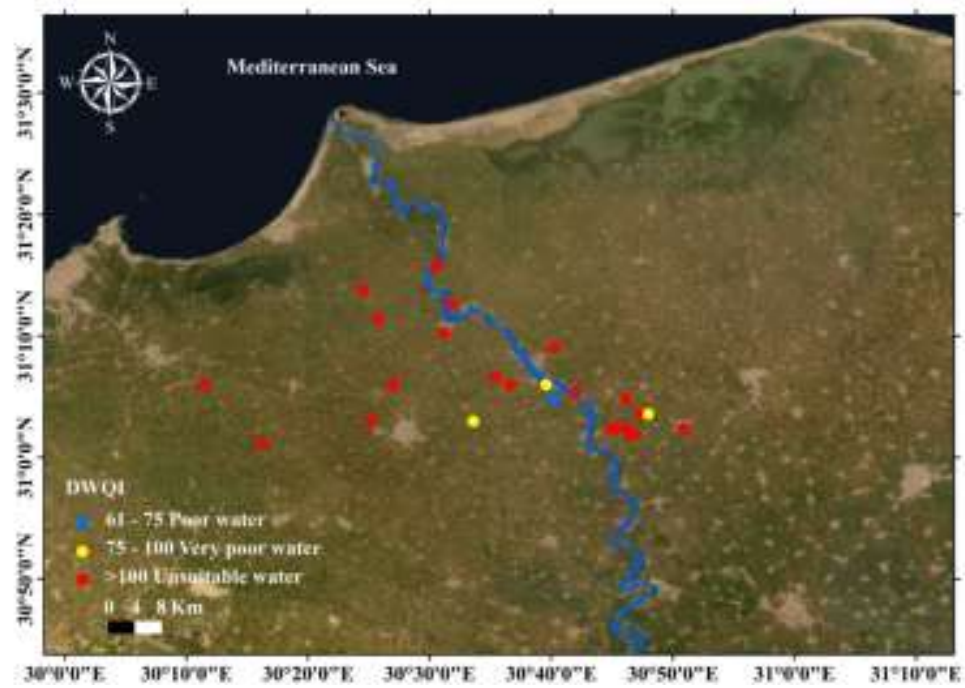

Fig. 19. Spatial variation of Drinking Water Quality Index (DWQI) in the study area.

\section{Conclusions}

The concerned area locates in the northern part of western Nile River Rosetta branch, Egypt. The branch dissected the area into two eastern and western portions (portion in Kafr El Sheikh Governorate and another portion in El Behira Governorate). Its surface is mostly flat of deltaic deposits, except for few negatives to the north direction where, the Idku and El Burullus lakes and Mediterranean Sea as a geomorphologic features. Geologically, sandy clay, clay and deltaic deposits of recent age expose the ground surface.

The electrical resistivity method (VES technique) has been utilized in this work to delineate the subsurface layers variations, the water content (aquifer layer), and the water salinity categories. Vertical electrical soundings were effective in vertically dividing the shallow section (down to $150 \mathrm{~m}$ ) into five layers of varying lithologic and water content. The obtained layers are surface layer of sand and clay (recent), underlain by clay layer (recent), and sand layer as an aquifer of the area (Pleistocene). The fourth layer is composed mainly of clay layer (Pleistocene), and finally, the fifth layer is the seawater intrusion zone. The aquifer thickness is increasing towards southeast direction, while it decreasing to north direction. The seawater intrusion zone is increasing to north direction (Mediterranean Sea coast). Hydrochemically, Piper diagram identifies three water types: $\mathrm{Na}-\mathrm{Cl}-\mathrm{SO} 4, \mathrm{Ca}-\mathrm{Mg}$ $\mathrm{Cl}-\mathrm{SO} 4$, and $\mathrm{Ca}-\mathrm{Mg}$ alkalinity. By using Gibb's diagram to map the samples. The groundwater points were clearly identified as being in the rock dominance and evaporation areas. Groundwater samples from the studied region fall into field 3 of the Chadha diagram, which represents the $\mathrm{Na}-\mathrm{K}-\mathrm{Cl}-\mathrm{SO} 4$ water type, illustrating the impact of seawater intrusion on the groundwater chemistry in the study area. According to the DWQI results, $3.85 \%$ of the collected groundwater samples were in the poor water class, $11.54 \%$ were in the extremely poor water class, and $87.86 \%$ were in the inappropriate water classes for drinking. These results ensure the effect of seawater intrusion on the entire study area, while the presence of River Nile decreased its effect especially at the southern portions.

\section{References}

Abd-Allah, A.M.A., (2008). Mesozoic-Cenozoic inversion tectonic of North $S$ integration of structural and basin analysis. Journal of Applied Geophysics.

Abdel Aal, A., Price, R.J., Vaiti, J.D., Shrallow, J.A., (1994). Tectonic evolution of the Nile - Delta, its impact on sedimentation and hydrocarbon potential. 12th EGPC, Egyptian General Petroleum Corporation Conference, Cairo 1, 19-34

Abdel Baki, A. A. (1983). Hydrogeological and hydrochemical studies on the area west of Rosette branch and south of El-Nasr Canal, Ph.D. Thesis, Fac. Sci., Ain Shams Univ., Cairo, Egypt.

Alewa, H., (2008). Hydro-environmental status and soil management of the River Nile Delta, Egypt. Environmental geology. 10.1007/s00254-008-1354-5

Barker, R. D., Venkateswara, R. T. and Then-garajan, M., (2001). Delineation of contaminant zone through electrical resistivity imagine technique. Current science journal. 81. no. 3, 277-283.

Brown RM, McCleiland NJ, Deininger RA, Oconnor MF (1972). A water quality index-crossing the psychological barrier. In: Proceedings of the International Conference on Water Pollution Research, Jerusalem, pp. 787-797.

Burger, H. R., (1992). Exploration Geophysics of the Shallower Subsurface. Prentice Hill, UK.

Chadah, D.K. (1999). A proposed new diagram for geochemical classification of natural waters and interpretation of chemical data. Hydrogeology journal. 7:431 - 439 .

Chatterjee, C. and Raziuddin, M. (2002). Determination of water quality index (WQI) of a degraded river in Asansol Industrial area, P.O. Raniganj, District Burdwan, West Bengal. Nature Environment and Pollution Technology, 1(2): 181-189.

Custodio E (1983). Hydrogeoquimica. In: Custodio E, Llamas MR (eds) Hidrologia Subterranea. Omega, Barcelona.

Durov,S.A (1948). Natural waters and graphic representation of their composition. Dokl.Aqad.Naud. SSSR 59:87 - 90.

El Arabi N. E. and Morsy W.S., (2013). Applying Integrated Ground- And Surface- Water Management (Case Study: Nubaryia 
Basin, West Delta, Egypt). Journal of American Science, Vol. 9 No. 6, pp. 43-53.

FAO (Food and Agriculture Organization).(1997). Seawater intrusion in coastal aquifers: Guidelines for study, monitoring and control. Rome, Italy: FAO Water Reports.

Fisher RS, Mullican WF (1997). Hydrochemical evolution of sodiumsulfate and sodium-chloride groundwater beneath the northern Chihuahuan Desert, Trans-Pecos, Texas, USA. Hydrogeol J 5(2): 4-16. doi:10.1007/s100400050102.

Fouad R. and Zhi Ch., (2010).Regional groundwater flow modeling in Western Nile Delta, Egypt. World Rural Observations, 2(2) ISSN: 1944-6543 (Print); ISSN: 1944-6551, pp. 37-42.

Gibbs RJ (1970). Mechanisms controlling world water chemistry. Science 170:1088-1090. doi:10.1126/science.170.3962.1088.

Gomaa, M. A. A., (1995). Comparative hydrogeological and hydrogeo- chemical study on some aquifer, west of Nile Delta, Egypt: Ph.D. Thesis, Fac. Sci, Ain Shams Univ., Cairo, Egypt.

Griffiths, D. H. and Barker, R. D., (1993). Two-dimensional resistivity imaging and modelling in areas of complex geology. J. Appl. Geophy. 29, 211-226.

Hamadan A. (2005). Evaluation of the Nile Valley aquifer from Aswan to Assiut using Geophysical and Hydrological methods, A thesis submitted to Faculty of Science, Aswan South Valley University.

Harms, J.C., Wary, J.L., (1990). Nile Delta. In: Said, R. (Ed.), The Geology of Egypt, Balkema, Rotterdam, pp. 329-344.

Hussein, I.M., Abd-Allah, A.M.A., (2001). Tectonic evolution of the northeastern parts of the African continental margin, Egypt. Journal of African Earth Science.

IPPC. (2008). Climate Change and Water. Technical Paper of the Intergovernmental Panel on Climate Change, edited by: Bates, B. C., Kundzewicz, Z. W., Wu, S., and Palutikof, J. P, IPCC Secretariat, Geneva, p. 210

Ismail, Y. L., (1994). Hydrological studies on the ground water reservoir in some localities under reclamation in west Al-Nubariya province. M.Sc. Thesis, Fac. Sci., Al-Azhar Univ., Cairo, Egypt.

Kawo N, Karuppannan S (2018). Groundwater quality assessment using water quality index and GIS technique in Modjo River Basin, central Ethiopia. J Afr Earth Sc 147:300-311.

Keary, P. and Brooks, M., (1998). An Introduction to Geophysical Exploration. Second edition. Blackwell Science, Inc. pp. 253.

Nessim RB, Tadros HRZ, Abou Taleb AEA, Moawad MN (2015). Chemistry of the Egyptian Mediterranean coastal waters. The Egyptian Journal of Aquatic Research 41(1):1-10. doi:10.1016/j. ejar.2015.01.004.

Nwankwoala HO, Udom GJ (2011). Studies on major ion chemistry and hydrogeochemical processes of groundwater in Port Harcourt City, Southern Nigeria. J Spat Hydrol 11(1):34-40.

Piper AM (1944). A graphic procedure in the geochemical interpretation of water-analyses. Eos Transactions American Geophysical Union 25(6):914-928. doi:10.1029/TR025i006p00914.

RamyaPriya R, Elango L (2018). Evaluation of geogenic and anthropogenic impacts on spatio-temporal variation in quality of surface water and groundwater along Cauvery River India. Environ Earth Sci. https ://doi.org/10.1007/s1266 5-017-7176-6.

RIGW/IWACO (1990). Hydrological inventory and groundwater development plan western Nile Delta region. TN77. 01300-9-02 Research Institute for Groundwater, Kanater El-Khairia

RIGW/IWACO (1999). Environmental management of groundwater resources (EMGR), Final Technical Report
TN/70.0067/WQM/97/20, Research Institute for Groundwater (RIGW), El Kanater El-Khairia.

Rockwork, (2004). Rockware Earth Science of GIS Geosoft.

Sakr SA (2005). Impact of the possible sea level rise on the Nile delta aquifer. A study for Lake Nasser flood and drought control project (LNFDC/ICC), Planning Sector, Ministry of Water Resources and Irrigation Google Scholar

Salem ZE and Osman OM, (2016). Shallow subsurface temperature in the environs of El-Nubaria canal, northwestern Nile Delta of Egypt: implications for monitoring groundwater flow system, Environ Earth Sci. 75:1241.

Sallam, 2018. Vision for Future Management of Groundwater in the Nile Delta of Egypt After Construction of the Ethiopian Dams. Journal of Hydrology, 9:3 DOI: 10.4172/2157-7587.1000302

Sami, K. (1992). Recharge mechanisms and geochemical processes in a semi-arid sedimentary basin, Eastern Cape, South Africa. Journal of Hydrology,139, 27-48.

Sarhan, M., Hemdan, K., (1994). North Nile Delta structural setting and trappin 9- mechanisms, Egypt. 12th EGPC, Egyptian General Petroleum Corporation Conference, Cairo 1, 1-18

Sharma, P. V., (1997). Environmental and engineering geophysics: Cambridge, England, Cambridge University Press, $475 \mathrm{p}$.

Srinivasamoorthy, K., Chidambaram, M., Prasanna, M.V., Vasanthavigar, M., Peter, J.,Anandhan, P., (2008). Identification of major sources controlling groundwater chemistry from a hard rock terrain-a case study from Metturtaluk, Salem district, Tamilnadu, India. J. Earth Sys. Sci. 117, 49-58. https://doi.org/10.1007/s12040-008-0012-3.

Tay CK, Hayford EK, Hodgsoni IOA (2017). Application of multivariate statistical technique for hydrogeochemical assessment of groundwater within the Lower Pra Basin, Ghana. Appl Water Sci 7:1131-11150.

Telford W. M, Geldart L. P. and Sherif R. E., (1990). Applied geophysics, 2nd edn. Cambridge University Press, Cambridge.

Tripp, A. C., Hohmann, G. W. and Swift, C. M., (1984). Twodimensional resistivity inversion. Geophysics, 49(10), 1708-1717. WHO (2011). Guidelines for drinking-water quality. Fourth edition. Geneva, Switzerland. 